\title{
Institutional Seed Financing, Angel Financing, and Crowdfunding of Entrepreneurial Ventures: a literature review
}

\author{
Johannes Wallmeroth \\ emlyon business school \\ Research Centre for \\ Entrepreneurial Finance \\ 23 Avenue Guy de Collongue, \\ 69134 Ecully, France \\ wallmeroth@em-lyon.com \\ Université de Lyon \\ Jean Moulin \\ iaelyon, Centre Magellan \\ 6 cours Albert Thomas, 69008 \\ Lyon, France
}

\author{
Peter Wirtz \\ Université de Lyon \\ U. Jean Moulin \\ iaelyon, Centre Magellan, \\ 18 rue Chevreul, 69007 \\ Lyon, France \\ peter.wirtz.fcs@gmail.com
}

\author{
Alexander Peter Groh \\ emlyon business school \\ Research Centre for \\ Entrepreneurial Finance \\ 23 Avenue Guy de Collongue, \\ 69134 Ecully, France \\ groh@em-lyon.com
}

This version: 12 May 2017

\begin{abstract}
Institutional financing, angel financing, and crowdfunding have evolved and matured in the entrepreneurial finance market and their field of research has progressed with it. Congruent to this, however, comprehensive literature reviews on these topics remain scarce. Herein, we provide an overview of a vast body of literature, presenting the contemporary state of research and succinctly identifying its subcategories. Additionally, we provide insight into major research trends and research gaps using a theoretical framework.
\end{abstract}

JEL Codes: G20 (General), G23 (Non-bank Financial Institutions, Institutional Investors), G24 (Venture Capital) Keywords: Business Angel, Business Angel Networks, Crowdfunding, Equity Crowdfunding, Seed Financing, Institutional Seed Financing, Venture Capital 


\section{Introduction}

Entrepreneurial finance is a vague term and can refer to numerous, also interconnected, elements of alternative investment finance. In this paper, we set the perimeter to discuss three of its principal components. With these three cornerstones, namely institutional seed financing (in the form of formal venture capital), angel financing, and crowdfunding, this paper identifies and analyzes academic literature in entrepreneurial equity finance.

To present the academic literature, we believe that presenting a framework upfront is essential in providing a connecting overview. The objective is to present the cornerstones of this paper in an interconnected style rather than individually. This provides us with the additional benefit of analyzing literature that investigates these market forces in interaction, beyond a mere investigation of each financing technique's individual contribution. Therewith, we provide a sense of overall market dynamics. Thus, we develop a theoretical framework which not only provides insight into the different sources of entrepreneurial equity finance but also guides this paper's structure. Due to the complexity of these fields, and the large amount of research that has been published, this paper focusses on selected publications and will not include publications dealing with financial capital provided by government funds, subsidies, banks, or other alternative sources of capital other than the aforementioned three financial mechanisms.

\subsection{Research in entrepreneurial finance: a conceptual framework}

Our literature review on entrepreneurial finance contributes twofold. First, it provides a better understanding of the characteristics and evolution of the players in the entrepreneurial equity finance market, individually and collectively. Secondly, it provides insight into the economic functions these financial mechanisms assume in the field of entrepreneurship and innovation (see figure 1). These functions can be categorized along the typical investment process into an entrepreneurial venture (Bonnet and Wirtz, 2012), reaching from the identification and evaluation of investment opportunities to the exit and return from realized investments. In other words, how can we explain the influences these players exert at different stages of the investment process and the outcomes they produce? How do these influences differ when these actors act together? This literature review shows that cognition, knowledge, skills, and other human and social capital resources are being recognized as part of the explanation (Bonnet and Wirtz, 2012; Cumming and Johan, 2007; Uhlaner et al., 2007, Wirtz, 2011). Managing information asymmetry and agency conflicts through monitoring and interest alignment are yet another prominent dimension (Cumming and Johan, 2008; van Osnabrugge, 2000). 
Figure 1 Economic functions of the financial mechanisms

The market for entrepreneurial finance has significantly evolved over the last thirty years. The first to enter the field are formal venture capitalists. They emerged in the US in the 1940s, and their professional practice became institutionalized by the mid 1980s, gradually spreading over the globe (Bruton et al., 2005; Gompers, 1994). This institutionalization and spread of the profession coincides with intensifying research efforts. This was primarily driven by the 1978 decision in the United States of altering the maximum capital gains tax rate which significantly increased the inflow of pension fund capital into venture capital funds as well as the amendment made to ERISA (Gompers, 1994, 1995; Swartz, 1991). With the growth of funds (Swartz (1991) notes that a fund managing USD 5 to 10 million in the early 1970 s to be impressive, compared to a size of 20 to 25 million by the end of that decade with a continuous growth in the 1980s) and the increase in institutionalization, research on professional VCs took off in the mid 1980s and has developed exponentially since. This can be seen from a keyword search in the Scopus database (see figure 2). This research helps understand the specific characteristics and working practices of the $\mathrm{VC}$ industry, such as its professional routines, investment behavior, syndication with other VCs, interaction with the entrepreneurs, exits, and venture success.

Figure 2 Scopus Publication statistics

The second curve (in red, figure 2) shows the inception and development of business angel research. Academic interest in business angels is much more recent and most research activity in the field has gained momentum only at the beginning of the new millennium. This is partly due to an already early-on established and repeatedly found fact that the angel market has an invisible component (Mason, 2006; Wetzel, 1983, 1987, 1994). As can be seen, new players in the entrepreneurial equity finance market enter the field at different points in time. The way they do business, alone and in connection with others, also undergoes change over time, adapting to technologies and more liberal markets as will be seen in this review. Business angels, also called informal venture capitalists, increasingly gained special interest throughout these adaptations because they are perceived as one potential solution to close the equity gap in early-stage financing. Business angels, being individuals who invest their own money, have progressively united and gathered in formal business angel networks (BANs) and groups in an 
ever more structured way to create a more visible market for angel finance. With government support aiming to narrow the funding gap, the development of BANs has found additional support, making the market increasingly visible and thereby facilitating research.

Crowdfunding, the newest development and influencer in academic entrepreneurial finance research, as also evident in figure 2 (green curve), has been the latest to enter the field. Ultimately, this progress can be traced to numerous sources, such as technological progress brought forth by the internet, the associated social media channels, and the still ongoing regulatory changes in financially savvy countries. These tools and circumstances enable crowdfunding to enter the alternative finance market as the youngest mechanism, with the term being coined in 2006 and research picking up traction at the beginning of the present decade (Everett, 2014).

Moving beyond the years of inception of these market practitioners, research in entrepreneurial finance today is a dynamic field. Many studies are dedicated to one specific mechanism (VCs, BAs, or crowdfunding), examining various questions related to one or more of the investment stages as sketched out above. Some works, however, set out to examine co-investments amongst the same type of financial mechanism. Others investigate the interaction between two or more different financial techniques, simultaneously (syndication) or over time (sequential co-investment over different financing rounds). Hence, we systematically categorize the vast body of literature on early stage venture finance per the following structure (see table 1).

Table 1 Categories of research in entrepreneurial finance

This framework, which helps outline the existing literature as well as the future research potential, also provides the layout for this paper. For one, it comprehensively defines these entrepreneurial finance players in their theoretical setting. It also outlines the modern empirical literature surrounding them. Furthermore, researchers who are keen on researching these fields require a solid understanding of their interactions. Given the vast amount of literature available for some topics and the little amount of research available for others, it is essential to provide a structure to this research and to make it comprehensible. The framework provides support with this challenge. Additionally, the interaction of these groups must also be understood, and as it represents a growing research topic, it must also be given a certain degree of emphasis. This paper aims to provide this information, theoretical as well as empirical, on the financial 
mechanisms and their collaborations throughout each stage of the investment process. Another point of interest is the development of research topics and key focal areas throughout the previous years which will also be discussed. For each of the mecahanisms, these historical developments and themes are different, occurring in other years or even decades, which will be discussed in-depth in the respective subsection for each financial mechanism.

\subsection{The role of data in entrepreneurial finance research}

Though formal venture capital literature, for instance, strongly developed since the 1980s, more modern research topics for this financial mechanism require new datasets with new variables, which can slow the progression of research even today. This notion is also seen when reading Barry (1994) who, for data available in the early 1990s, claims that research in the field of venture capital is complex for multiple reasons. These reasons include the difficulty of gathering data on private investments - a difficulty that the author notes is slowly overcome by the creation of new databases at the time of the publication, shedding light on venture capital related topics still unknown in the 1980s. This process is repeated with the discovery of new research questions (such as ones related to syndication and co-investments) which often require new databases with new variables. This indicates that researchers firstly seek to identify financial mechanisms and players in the market with the subsequent objective of understanding their role as well as their behavior. This enables scholars to classify these financial products and players, and place them in the field of entrepreneurial finance, which ultimately evolves into the pursuit of more sophisticated research questions. This process is closely tied to the availability of data, for an interesting research question ultimately requires the corresponding data to answer it. Following the initial process of classifying the behaviors, (mostly) empirical studies, of which a great deal are survey and interview based publications, examine the influence and impact, as well as implications, of the previously studied behavior. This research step of understanding the financial mechanism is (in the case of VC and crowdfunding research) accompanied by scholarly work on the factors of success of such investments.

The remainder of this article is structured along five sections. The subsequent three sections cover the individual mechanisms in the order of inception - each being sub-sectioned by the framework's three investment stages. Thus, the paper continues with a section on venture capital literature followed by business angel literature and then crowdfunding literature. These sections are then complemented by a section based on their interactions after which the paper concludes. 


\section{Venture capital}

This section is dedicated to past, present, as well as future research potential. It is structured to provide an understanding of this financial mechanism in terms of past development in the market by beginning with a definition and characteristics. After, we will outline venture capital research development since its inception, discussing thematic hotspots. Subsequently, the three stages, as outlined in the framework introduced earlier, will be covered. Following these subsections, we provide a brief conclusion, revolving around the theoretical evolution of $\mathrm{VC}$ research, that seeks to tie in the reviewed literature with the theoretical framework presented in the introduction.

\subsection{Definition, relevant markets, and general characteristics}

Institutional seed investors (also referred to as venture capitalists or formal, professional venture capitalists) were first formally founded in 1946 and raise funds from individuals, organizations, endowments, pension funds, banks, sovereign wealth funds, family offices, governments, and insurance companies to be invested in early stage ventures that offer high reward potential through an equity stake, yet also high risk (Barry, 1994; Carey et al., 1993; Fenn et al., 1997; Gompers, 1994; Gompers and Lerner, 2001; Sahlman, 1990; Weston et al., 1978). Institutional investors are known to invest by themselves or in co-investment which can include other institutional seed investors or also other financial mechanisms in the entrepreneurial finance market (Bonnet and Wirtz, 2012). VC investors formally focus on elements such as screening, contracting, monitoring, as well as determining the time to exit the investment (Gompers and Lerner, 2001; Fitza et al., 2009; Gorman and Sahlman, 1989; Rosenstein et al., 1993; Sahlman, 1990; Sapienza et al., 1996; Tyebjee and Bruno, 1984). They identify themselves as active investors who take part in strategic development of the venture as well as the occasional partaking in operations (Berger and Udell, 1998). Warne (1988), for instance, describes venture capitalists as a mixture between capital providers and consultants. These investors usually focus on specific niches (Barry, 1994; Gupta and Sapienza, 1992; Norton and Tenenbaum, 1993; Ruhnka and Young, 1991). Barry et al. (1990) finds that this industry specialization helps with the monitoring process of portfolio ventures (see also Gompers, 2005). Overall, however, numerous industries such as technology, healthcare, manufacturing, and services are covered. Fitza et al. (2009) note that the involvement of VCs varies depending on investment duration. Over time, the institutional investor engages more in operational and strategic aspects of the venture whereas, during initial investment rounds, the $\mathrm{VC}$ is primarily concerned with the identification of a high potential venture. Furthermore, 
these are typically industries which feature large information asymmetries and allow the institutional investor to apply their know-how, economizing and capitalizing on this asymmetry (Amit et al., 1998; Gompers, 2005).

VCs can also be labeled as traditional venture capital and corporate venture capital. This distinction is discussed by Hellmann (2002). The author claims that corporate venture capitalists, in addition to financial incentives exhibited by traditional VC investors, these corporate investors have a strategic motivation to invest as well.

\subsection{Research trends over time}

Institutional investors originated in the United States, specifically the east coast, and spread to the west coast in 1957 (Gompers, 1994). Subsequently, venture capital spread to the United Kingdom in the late 1970s, shortly followed by continental Europe in the early 1980s. The transition of VCs to Asia kicked off towards the end of the 1980s and has since grown significantly (Bruton et al., 2005). Fenn et al. (1997) note that it was not until funds became organized in the late 1970s through limited and general partnerships that growth became noticeable and expanded exponentially through the 1990s.

Further, it was during the late 1970s and 1980s that equity funds were increasingly invested by fund managers whereas, prior, equity funds came from wealthy families, corporations, and financial institutions. This form of investing was derived from an extant existence of information asymmetries and the difficulty of aligning incentives. Gompers (1994) outlines another shift in VC investing with the introduction of pension fund money becoming available as the VC industry matured during the second half of the $20^{\text {th }}$ century through the amendment to ERISA in 1979. This act explicitly enabled pension funds to invest with formal venture capitalists. This was prohibited prior to 1979 by the Employee Retirement Income Security Act which was enacted in 1974. Swartz (1991) places another turning point with the 1978 decision of altering the maximum capital gains tax rate after which additional capital became available from pension funds. Upon this increase in investible funds, institutional investors began to form more formal proceedings, from identification and screening practices to deal structuring and divesting, or harvesting, the investment. Gompers (1994) notes that this shift towards pension funds as fund-capital providers also impacted the stage that ventures were being financed in. From 1980 to 1988 , VCs shifted from seed and early stage financing to later stage financing ( $25 \%$ of VC investments in 1980 were into seed and start-up which declined to $12.5 \%$ 
by 1988) where a large segment of VC funds were used in LBOs (leveraged buyouts). These changes were also influenced by the investment duration imposed on institutional investors. The shorter life-time of LBOs was sought after by fund managers. For the European VC counterparts, Ooghe et al. (1991) investigate the development of venture capital looking at data from 1984 to 1989 . Their findings are that only a small percentage (14\%) is invested in early stage start-ups by VC funds. The authors compare this figure to $30 \%$ in the United States (the difference between Gompers, 1994 and Ooghe et al., 1991 partly originates from the use of yearly figures versus the average between 1984 and 1989). The authors conclude that the European market varies from the US VC market in terms of its characteristics and that the EU VC market also varies within itself, due to different country-related structures and policies an issue still relevant to contemporary research.

These shifts in the 1970s and 1980s are also visible when viewing the publication in journals. Simply, when looking at databases which cover the vast majority of journals in numerous fields of research (JSTOR, ProQuest, Science Direct, Wiley), publications in financial journals with the words 'venture capital' in the article title ${ }^{1}$ began in 1968 (Financial Analysist Journal ${ }^{2}$ ), 1978 (a PhD review in Financial Review ${ }^{3}$ ), 1979 (Journal of Finance ${ }^{4}$ ), 1983 (The Journal of Financial and Quantitative Analysis ${ }^{5}$ ), 1988 (Journal of Applied Corporate Finance ${ }^{6}$ ), and 1990 (Journal of Financial Economics $^{7}$ ). The first publications focusing on venture capital, however, originate in non-finance titled journals (i.e. Quarterly Journal of Economics: 1941; Journal of Small Business Management: 1969; Industrial Marketing Management: 1972; R\&D Management: 1972). These articles, as well as those articles later published in tandem to finance related journals, focused on the geography, government programs, and strategic aspects such as venture capital's impact on corporate development (see also Strategic Management Journal and The Professional Geographer). The shift from research questions in the early days, which relate to the characteristics of this financial mechanism, did not take place until the mid 1980s which is when the financial aspect became more thoroughly researched - or at least it was not until this time that financial journals began to gain more interest. With the increase in

\footnotetext{
${ }^{1}$ Searching for "venture capital" in the articles' keywords yielded no relevant results for searches from 1900 to 1990.

${ }^{2}$ Rotch, 1968.

${ }^{3}$ Hoban, 1978.

${ }^{4}$ Cooper and Carleton, 1979.

${ }^{5}$ Martin and Petty, 1983.

${ }^{6}$ Sahlman, 1988.

${ }^{7}$ Barry et al., 1990.
} 
publications throughout multiple journals, publications increased from 63 in the 1970s to 350 in the 1980s, further growing to 675 in the 1990s (see figure 3).

Figure 3 Publication statistics for Venture Capital publications by decade

Looking at the initial articles and dissertations in the field of venture capital, these focus on measuring success (Rotch, 1968; Hoban, 1978), fund performance (Martin and Petty, 1983), and looking at the agency problem and its effects on VC investments (Cooper and Carleton, 1979) which led to identifying aspects of venture capital investments, such as that they are highly risky, have investment durations of five and more years, and that there is no secondary market after the initial investment has been made and that subsequent investment rounds are required for a successful exit. Papers that followed in the 1980s (such as Cooper, 1985; Gorman and Sahlman, 1989; MacMillan et al., 1985; Sahlman, 1988; Stevenson et al., 1987; and Tyebjee and Bruno, 1984) focus on the investment process, the behavior, and the activities of venture capitalists. Bygrave $(1987,1988)$, on the other hand, begins to study the syndication and networks of VCs - a focus which yielded the reward of still being cited on numerous occasions nearly 30 years later. Research in the 1990s continues to evolve from measuring success and defining the role and activities of VCs up to the end of the 1980s, to summarizing literature and assessing future research directions and rationalizing VCs' existence (Barry, 1994; Fenn et al., 1997; Gompers, 1994; Gompers and Lerner, 1998; Sahlman, 1990; Swartz, 1991 ) as well as researching to understand more intricate settings (i.e. Black and Gilson, 1998 who clearly find a difference of $\mathrm{VC}$ activities between bank and stock-centered economies). Lerner (1994a, 1994b, 1995) also extends literature towards more targeted paths through the study of syndication, decision-making, and influence of VCs on the firms they invest in. Since the turn of the millennium, literature emphasizes cross-border investments as well as networks (syndication and co-investments) and governance. Some authors, however, such as Kaplan and Strömberg $(2002,2004)$, study more specific fields, such as contracting.

Co-investment networks of institutional seed capital providers have been treated throughout literature (see e.g. Bygrave, 1988; Lerner, 1994; Reiner, 1989; Sorenson and Stuart, 2001; Hochberg et al., 2007; Walske et al., 2007). It is important to include information on these networks in this section in order to provide an insight into their specific development. For instance, Reiner (1989) finds that in the early years of the venture capital industry, syndication intended to diversify the portfolio, spread risk, and maximize returns. With the maturity of the 
industry, this behavior may have declined, although, syndication and networks amongst VCs is still, at minimum a source of deal-flow. Hochberg et al. (2007) note that venture capital firms that have a greater network experience also experience superior fund performance. Their findings also apply to the venture itself, which is more likely to successfully navigate other investments and successful exits. Lerner (1994a) finds that initial co-investment rounds by institutional investors include other institutional investors with a similar degree of experience. Subsequent funding rounds, however, can also include less experienced institutional investors.

Other studies on the syndication effects of institutional investors include Brander et al. (2002) who argue that syndicated investments provide additional input, a second opinion, by an outside institutional investor whilst also contributing additional managerial know-how. Their findings include higher investment returns when the investment was syndicated, allowing interpretation that such an increase in return stems from the managerial know-how generated through syndication - based on the argument that non-syndicated investments do not require a second opinion.

Chemmanur and Tian (2011) argue five principal points of syndication: (1) that more complex ventures are candidates to seek syndicated investment structures, stating in turn that (2) more specialized institutional investors are more attracted to the concept of syndication than institutional investors practicing a general investment approach. Furthermore, (3) ventures seeking syndicated investments throughout multiple investment rounds are more likely to experience successful exits than ventures that switch to non-syndicated investment structures later. In more detail, (4) consistent membership of the syndication networks throughout multiple funding rounds increases the success rate of exits rather than when syndication members change throughout the funding rounds. And lastly, (5) successful funding through a syndicated structure provides the institutional investor with a positive experience, increasing the likelihood of syndicating investments again in the future. Nevertheless, Lockett and Wright (2001) point out that VCs are heterogeneous entities. Particularly, differences amongst institutional investors arise depending on the investment stage that a $\mathrm{VC}$ focuses on which can, naturally, have an impact on the behavior exhibited during syndication. Therefore, the definition of venture capital networks as well as venture capital syndication, including the exhibited behaviors, remain partly unknown or at least unclarified and are evolving over time. Though the minimization of risk and the maximization of returns are still two major aspects, the knowledge gained by the syndicating partners, and other aspects and effects of syndication 
which are also noticeable, which have been less studied, have either always existed or increased over time. To this end, the question remains whether such syndication-related traits were discovered due to newer datasets or newer research questions. Alternatively, it could also be linked to the development of more sophisticated theory being borrowed from the strategic management and entrepreneurship literature, which puts heavier emphasis on cognitive resources and managerial capabilities than the traditional finance literature.

\subsection{Pre-Investment stage: deal-flow, selection, and evaluation}

Even though literature on institutional seed capital providers is extensive, at least in comparison to the other two financial mechanisms, the sourcing of deals as well as the selection and evaluation are still not fully researched. Though institutional investors have multiple sources of generating deal-flow, the most researched ones are spin-offs and ventures founded by serial entrepreneurs (Da Rin et al., 2013). Another major source of deal-flow is the network between venture capitalists. Even though these three sources are not the only tools for VCs to generate deal-flow, they are the most studied. In terms of selection, VCs differentiate themselves as well. Many VCs focus on industries, geographic settings, as well as the investment stage. In order to evaluate these prospect ventures, VCs assess the risks of the investment which can lie in the risks of the market but also in the trust between the people involved in the investment process.

\subsubsection{Spin-offs}

As for deal-flow, spin-offs are found to be an important tool for VCs. They are ventures that are founded by employees of already existing companies. Research indirectly shows that this is one area where entrepreneurs come from. Cooper (1985) finds that $60 \%$ to $70 \%$ of entrepreneurs founded a venture in a field in which they had previously been employed. This phenomenon is also found by Bhide (1994) who notes that a significant portion of entrepreneurs implemented ideas that originated during their prior employment. It is confirmed by others as well, including Gompers et al. (2005) who note that on average from 1986 to 1999 , $45 \%$ of entrepreneurs stem from public companies. Additional, more in-depth, research on these investments, for instance how such ventures fare against start-ups originating from other sources of deal-flow, remain to be studied. 


\subsubsection{Serial entrepreneurs}

Another major source of deal-flow, the serial entrepreneur, is explored in more depth - though many questions remain unanswered all the same. Literature claims that it is - under some circumstances - unlikely for an entrepreneur to pursue repeat financing by the same institutional investor for a new venture (Bengtsson, 2013). Though this may seem counterintuitive for the argument of generating deal-flow, it is explained by the author on two fronts. First, the subsequent venture may pursue success in a different industry to that which the original $\mathrm{VC}$ focuses on and, second, it may also lie outside of the geographic scope of the VC. Thus, the serial entrepreneur is more mobile. The amount of information that the VC gathers about the entrepreneur throughout the initial relationship is also a factor and gathering additional private information leads to a higher likelihood of repeat financing. In numbers, the author finds that one in 10 investments leads to a repeat investment with the entrepreneur, whilst one in three serial entrepreneurs receives a second funding. This provides evidence that serial entrepreneurs are a potential source of deal-flow, depending on the given circumstances, even a deal-flow generator for the same fund on more than one occasion. Another emphasizing factor of serial entrepreneurs as a source of deal-flow is the finding of Gompers et al. (2010) who show that between 1986 and 1994, the ratio of serial entrepreneurs being funded by venture capitalists rose from $7 \%$ to nearly $14 \%$. Also of note is their finding in an earlier paper where the same authors examine the effect of skill on success in entrepreneurship and venture capital: Gompers et al. (2006) discover that entrepreneurs with a positive track record are more likely to be successful in these areas than newcomers or than entrepreneurs who have failed in the past. Wright et al. (1997), who study the relationship between VCs and serial entrepreneurs, note that, although VCs prefer to use a known entrepreneur, the actual number of entrepreneurs who get repeat funding is low. Their finding of lower repeat financing is comparable to Bengtsson (2013). Wright et al. (1997) find that, alternatively, VCs use such individuals in consulting roles. Therefore, the role of serial entrepreneurs in generating deal-flow for institutional investors is far from definitive and may also depend on the geographic and cultural settings.

Westhead and Wright (1998) note that successful serial entrepreneurs also have their personal wealth and savings as a source of finance, which is found to be true based on their survey (138 serial entrepreneurs answer they use personal wealth or family and friends for initial financing versus 19 who answered no). This finding suggests that the deal-flow from serial entrepreneurs, though present, is perhaps a rather secondary source due to the independence of these 
entrepreneurs. Serial entrepreneurs are also found to be more selective in terms of the industry in which they invest, placing more emphasis on market related risks rather than agency conflicts, as well as preferring deals in the form of co-investments whilst also being less active an investor compared to non-serial entrepreneurs (van Osnabrugge, 1998). These traits, including a serial entrepreneur's higher expectations on initial expected rate of returns as well as realized expected rates of returns, may also affect the relationship between institutional investors and the serial entrepreneur - acting as a business angel - which may have an impact on the likelihood of deal syndication and therefore deal-flow between the two parties. Nevertheless, research on serial entrepreneurs remains scarce.

\subsubsection{Networks as a tool for deal-flow}

The third source of deal-flow, the network amongst VCs, is analyzed by many including Bygrave (1988) who finds that the information that is shared within the networks of venture capitalists are noteworthy sources of investment opportunities. Lerner (1994a) notes that syndication is commonly exhibited already in initial investment rounds, where the co-investor has similar levels of experience as the lead VC. This trait of network utilization amongst VCs is empirically expanded by Hochberg et al. (2015) who show that co-investments between institutional investors are more likely reflected on the best available investment partner, and this partner's network, rather than similarity-based matching (the similarity between resources and characteristics, for instance). In other words, a $\mathrm{VC}$ rather invests with another $\mathrm{VC}$ who fits the strategic needs and has a useful network that will allow the investment to succeed, rather than looking for a VC partner who practices similarly, has identical investment strategies, and has the same reach with its network. Gompers et al. (2008) find that it is an institutional investor's industry focus that also allows for stronger contacts and networks to be created, with the potential and objective of channeling investment opportunities.

A somewhat counter viewpoint to networks being a deal generating tool, and considering that Ruhnka and Young (1991) note that the decisions VCs make when deciding to invest into a venture are complex and the task of measuring risk are difficult due to scarce financial data being available, they may also be used as a resource to gather information rather than investment opportunities. For instance, on a deal-level, beyond the effect of VC networks on generating deal-flow, Lockett and Wright (2001) show that VC syndication focuses significantly more on financial measures than the exchange of resources or generating deals. The authors argue that the exchange of resources on syndication at the deal-level play a less 
profound role, acknowledging that the findings are different from those of Bygrave (1987, 1988). This suggests that the exchange of resources is more relevant for generating deal-flow. This difference in finding, however, may originate from the samples used, US versus the UK. Manigart et al. (2006) also find that reasons for syndication amongst VCs differ between the US and Europe. These differences include the portfolio management motives - in contrast to individual deal management motives. Furthermore, it is the sharing of risk, diversification, and opportunities for larger deals that motivates VCs to syndicate. The authors find that for early stage deals, adding value is a more pronounced reason for syndication than for later stage investments. Overall, however, the scholars find that the financial motive to syndicate is the strongest, regardless of early or later stage investments, with a differentiation between large and small funds. Moreover, the financial motive for syndication decreases for larger and later investment stage funds. For early stage investment funds, the reason to syndicate, in regards to deal-flow motivations, is higher than for larger funds. The rationale being that larger funds need to invest into more ventures, thus requiring access to more deal opportunities and larger networks. The authors claim fund size may be the reason why their findings are partly different from previous research, explaining that European funds are smaller than US funds, on average. Therefore, adding to the differences found between Locket and Wright (2001) and Bygrave $(1987,1988)$, the fund size may also play a role in reasons to syndicate.

\subsubsection{Other deal origination processes}

One noteworthy literary contribution towards VC deal-flow is Tyebjee and Bruno (1984) who conduct a survey on the pre-investment stage that assesses the origination, screening, evaluation, structuring, and even post-investment of VC deals. In their survey results, the authors identify three sources of deals. The first represents about a quarter of deals which originate from cold calls made by entrepreneurs. The most significant source of deal-flow came from referral of either other VCs, acquaintances, former investees, or banks whilst a third and final source of deals originate with active search performed by the institutional investor. It is found that the primary reason for the large number of referrals by other institutional investors is their desire to syndicate the investment, where the referring VC wishes to act as the lead investor. Their findings emphasize the importance of networks, which is picked up on in literature by Bygrave (1987, 1988), Lerner (1994a), and more soon after (see e.g. Hochberg et al., 2015; Lockett and Wright, 2001). 
Overall, the sourcing of deals is not fully understood. Although the primary sources have been identified, the exact interactions remain largely unknown as well as the evaluation of success - whether where the deal originates from plays a role on the successful sale or IPO of the venture. One other major gap in research are the international discrepancies - as indicated by the findings of Lockett and Wright (2001) versus Bygrave $(1987,1988)$ - in regards to network distinctions in different countries. Furthermore, due to the continuing increase in sophistication by the institutional investors (their networks, market size, etc.), the sourcing of deals may also be constantly adapting. These developments are complemented by the increasingly sophisticated technologies which also prompted the creation and development of crowdfunding. These developments and interactions remain unexplored.

\subsubsection{Venture selection}

Yet another under-researched topic is the target selection of institutional capital providers. In terms of the screening process, Tyebjee and Bruno (1984) note that one element is the size of the deal. This criterion is easily set, the authors find, as the VC must assert a minimum investment amount due to the necessity of focusing on a limited number of ventures in its portfolio and its minimal personnel. The upper end of a deal, however, is much more flexible due to the possibility of syndicating with another institutional investor. A second vital aspect is the industry that the investment is in, an industry which must be familiar to the VC (a criterion utilized by 29 of 46 surveyed VCs). Another, yet less often used criterion ( 9 of 46 surveyed VCs), is the location of the venture. A final criterion assessed, and used frequently, is the stage of the investment ( 22 of 46 surveyed VCs). The authors find that five essential criteria are used to evaluate a venture: (1) market attractiveness, (2) product differentiation, (3) managerial capabilities, (4) environmental threat protection, and (5) cash-out potential. The authors continue to test these criteria on the perceived risk and the expected return of an investment. It is found that, of these five criteria, two have a noteworthy impact on the risk of the investment: managerial capabilities and environmental threat protection. When asserting the influence on expected rate of return, market attractiveness and product differentiation have the strongest impacts.

In more detail, and in line with the attractiveness of the market, Gompers et al. (2008) find that the investments of institutional investors who hold significant experience in a given industry are more susceptible to public market signals and changes than the investments of VCs with less experience in the industry. The authors' findings imply that more experienced VCs are 
able to maintain their investment performance during market growth and peak years. The reason for this ability is noted to be the element of human capital. Further, however, the effect of industry-related experience still requires further analysis. MacMillan et al. (1985), as Tyebjee and Bruno (1984), provide additional insight into the overall components of target selection and associated risks used to evaluate a deal.

MacMillan et al. (1985) identify the use of six criteria of risk in order to assess an investment opportunity. They note these criteria as (1) the risk of the investment failing, (2) the risk of not being able to divest, (3) the risk of failure to implement, (4) the competitive risk, (5) the risk of management failure, and (6) the risk of leadership failure. In the context of these six risks, the authors identify three types of venture capital behavioral traits. The first group intensively evaluates risks (3) and (4), namely competition and implementation. The second group of venture capitalists focuses solely on risk (2), the ability to exit the investment if required. The third and last group of venture capitalists focuses on minimizing all six risks by maintaining as many options as possible. Using these criteria, the overall selection process is studied by Vinig and de Haan (2003) who identify that venture capital firms with passive deal-flow generation focus more on a hierarchical decision approach compared to actively seeking deal-flow institutional investors.

On a related note, Parhankangas and Hellström (2007) study the relationship between experience and risk reduction. The authors note that a VC's experience drives risk perception and, by extension, the risk of their investments. This behavior can be attributed to overconfidence as well as the illusion of control or simple risk speculation associated with the field of entrepreneurial ventures. Supporting these overall findings and behavioral traits of institutional investors is Fitza et al. (2009). The authors note in their paper that institutional investors appear to have similar selection criteria. This explains their finding that institutional investors are not a predictor of portfolio company performance variance in the first inter-round time-period - suggesting that VCs are identically able to identify high potential ventures.

These risks, however, are shown by Ruhnka and Young (1991) to vary depending on the stage of the investment. The authors portray these risks over 4 stages of development: (1) seed stage, (2) start-up stage, (3) implementation stage, and (4) the competitive stage. They note that in terms of seed-stage investments, the basics of the business concept play the most vital role. Specifically, the VC looks at whether the proposed product or concept is implementable and 
whether the market potential is sufficiently significant. At a slightly more mature stage, though the business concept is still the focal point, the risks are more concentrated on the technological and economic practicality. In other words, how high is the likelihood of a failing product or an insufficient market share for the venture to become successful. The third stage, at which the product or service is implemented, is associated with the risk of management not delivering the required work and not conducting enough financial control. It is also at this stage that insufficient competitive potential renders the product unsuccessful. The fourth stage surrounds itself entirely with competitive and growth related risks. More specifically, increasing existing sales or market share. When exiting an investment, risks do also remain. These are most often associated with the risk of retaining market share and the rise of other competitors. The authors note, though, that their investigation did not discriminate between industries which can produce highly heterogeneous interpretations of risk.

Amit et al. (1998) find that institutional investors seek out industries in which the degree of information asymmetry is high whilst looking for investment opportunities with minimal asymmetry related costs within those industries. Though information asymmetry generates monitoring costs, the ultimate goal is to invest in ventures where the returns have lower variance. These, as noted in their theoretical framework, are industries such as biotechnology, which are more difficult to monitor. However, given the competitive advantage of the institutional investor in terms of monitoring, this difficulty provides VCs with an advantage over other investors. The target choice of an institutional investor, therefore, ought to be a venture with experience rather than an immature start-up. Bygrave (1988) and Gompers (1995) also find that venture capitalists focus on highly innovative ventures and the early stage investment opportunities that bring with them high degrees of uncertainty and risk. Norton and Tenenbaum (1993) survey 98 VCs and discover that early stage VCs specialize on specific industries. Furthermore, institutional investors tend to specialize on the stage of financing as well. The authors note that VCs aim to reduce risk in their portfolio as well as constructing a reputation that will also lead to the VC being integrated into information sharing networks. Such network integration is aimed at increasing possible deal-flow.

Gupta and Sapienza (1992) conduct a survey based investigation into the targeting of ventures by institutional investors. The authors find that VCs which focus on early stage financing opt for lower diversity of the industries that they finance. Furthermore, these early stage financiers also choose to invest into ventures that are located close by. It is noted that this compares to 
corporate venture capital firms who, also seek less diversity, but broader geographic range. Larger VCs do not prefer specific industries or geographic settings. The authors highlight the heterogeneity of institutional investors and the necessity for them to attract and market themselves correspondingly whilst also pointing out the diversity of capital sources for the entrepreneur.

\subsubsection{International and cross-border investing decisions}

With a more global approach, Jeng and Wells (2000) analyze the determinants for venture capital investments on a macroeconomic level across 21 countries. Their paper, which launched much research into the determinants of when institutional investors invest, identifies IPO activity as one of the primary determinants of venture capital activity in a country. By looking at early and later stage investments of institutional investors, the authors discover that these stages are affected differently by the investigated determinants. For instance, early stage investments are affected by labor market issues whilst later stage investments are not. These determinants have since been studied more thoroughly, with larger samples as well as for different regions (see also Balboa and Martí, 2001; Cherif and Gazdar, 2011; Cumming et al., 2010; Félix et al., 2007; Gompers and Lerner, 1998; Groh and von Liechtenstein, 2009; Groh and Wallmeroth, 2016; Leleux and Surlemont, 2003; Nahata et al., 2015; Romain and van Pottelsberghe de la Potterie, 2004). Another more recent study on cross-border determinants was conducted by Moore et al. (2015) who identify that normative and cultural-cognitive distinctions between countries can lead to less cross-border VC activity; where normative differences are those of social norms, values, and beliefs and cultural-cognitive differences between the knowledge and understanding of people between countries. Regulative differences, however, are found to be insignificant. The authors note, however, that further research is required to fully understand the extent of their regulatory findings. Overall, though, the findings indicate that norms and cultural-cognitive differences matter and can impact the $\mathrm{VC}$ activity between countries.

Khavul and Deeds (2016) investigate the syndication of initial deals in the emerging market of Israel and discover that VCs who share industry related investment experience increase the probability of syndicating a deal with a similarly experienced institutional investor. Additionally, the authors find that institutional investors who invest in an emerging market are likely to continue investing and forming new partnerships through syndication. In doing so, the quality of the $\mathrm{VC}$ is also an important factor as it is a status symbol. When a newcomer to the 
emerging market seeks to invest with a local partner, this status, as well as the experience of the local VC, play significant roles. When these foreign institutional investors look for other foreign VCs to co-invest with, the priority lies in finding a VC with similar industry-related investment experience.

\subsubsection{The human element}

Another important aspect of deal evaluation is trust. Bottazzi et al. (2011) show that trust is a vital element for institutional seed investors when it comes to investment decisions. Their paper also notes that the national configuration of partners of the institutional capital provider plays a role. These findings are also influential throughout the contracting phase. Furthermore, when it comes to matching entrepreneurs with institutional investors on a more personal level, Bengtsson and Hsu (2010) find that ethnicity and attendance at a top university leads to a higher likelihood of coming together. Moreover, the lifecycle stage of the venture appears to play a more important role in determining a match than the entrepreneur's background when it comes to similarities with the institutional investor's professional capabilities.

In terms of the individuals involved, MacMillan et al. (1985) point out that it is the experience or personality of the entrepreneur that plays the most important role in a venture capitalist's decision to invest in a venture. The authors further note that a balanced management team is a vital point of interest for an institutional investor. These findings are indirectly concurred by Kaplan and Strömberg (2004) who show that strong management teams obtain more appealing contracts and are more probable to IPO. Additionally, venture capitalists consider the overall attractiveness of the venture opportunity as well as the terms of the deal. The attractiveness of a venture is also reflected by the industry which it is in and is also an essential aspect of target selection.

\subsubsection{How the pre-investment stage can predict success and failure}

MacMillan et al. (1987) study the influence of screening attributes on the success and failure of a VC-backed venture. The authors identify three principal screening criteria for failing ventures and four screening criteria for successful ventures. In terms of failing ventures, startups most likely to be funded but ultimately fail are those with (1) an inexperienced management team, lack of a product prototype, and unclear market demand. The other two criteria revolve around market staying power. When a start-up has (2) sufficient market staying power, however, also experiences high market competition which results in decreasing survival efforts 
of the funded venture, or (3) superior market staying power proving a market for the product, but a therewith creation for competition combined with a lack of product protection brings failure of the original start-up. The screening criteria for successful ventures all revolve around qualified management teams. Therefore, a start-up in the high-technology sector should firstly have an experienced team as well as enough market staying power. The second criterion for success indicates that the management team has low credentials, however, high product protection. The third criterion represents ventures with a management team that demonstrates a market for the product and has high product protection. Lastly, the authors find that some ventures which are in the low-technology sector, however, requiring critical distribution skills, are also more likely to be successful. The scholars conclude that these criteria for success revolve around two major implications: protection from competition and market acceptance of the product. The authors note, however, that their study is based on ventures that are funded, rather than ventures which may be funded, an analysis which returns different results (see e.g. MacMillan et al., 1985; Tyebjee and Bruno, 1984). The primary implication of this discrimination is that the two principal criteria (protection from competition and market acceptance of the product) are market related rather than product or entrepreneur related.

Table 2 summarizes some of the literature's findings in order to highlight the most prevalent elements of the pre-investment stage. The papers can each be categorized: Tyebjee and Bruno (1984) assess criteria for venture selection, MacMillan et al. (1985) analyze the risks involved in funding a start-up, Ruhnka and Young (1991) distinguish between the stages of the product and start-up, and MacMillan et al. (1987) look at attributes of funded ventures that failed.

Table 2 Selection criteria by venture capitalists

\subsection{Investment stage: ownership structure and contracting}

Venture capital investors tend to invest, though not exclusively, in high-technology ventures (Gompers, 1994; Gompers, 2005; Gompers and Lerner, 2001). Such ventures endure in highly complex environments (Bygrave, 1988) which, as Amit et al. (1998) note, are industries in which the degree of information asymmetry is high. Contract theory, which outlines the numerous hindrances to cooperation between people, identifies contracts as the mitigating factor to these obstacles. The theory is being used to assess the institutional investor field of entrepreneurial finance for some time (see Hart and Helmström, 2016 for more information on contract theory). The ensuing risks, as identified by MacMillan et al. (1985) call for monitoring 
practices to be implemented. For the venture capitalists to ensure that these monitoring practices are upheld and in order to provide them with the legal claim to monitor, contracts are used. The terms and conditions included in VC contracts usually reflect the VC's preinvestment due diligence and risk analysis (Kaplan and Lerner, 2010). Gompers (1995) finds that institutional investors increase monitoring practices simultaneously as these risks, or the resulting agency costs, increase (see also Sapienza et al., 1996 who find that with higher agency risks, monitoring practices are augmented - depending on the length of the relationship between the institutional investor and the entrepreneur).

\subsubsection{Contracting and agency theory}

Gompers (2005) investigates agency conflicts between VCs and entrepreneurs and the influences on monitoring and staging of investments. The author looks at the influence of asset tangibility, growth options, and asset specificity on agency costs, finding that agency costs increase with decreasing asset tangibility, increasing growth options, and larger asset specificity. As the expected agency costs increase, the author notes, the frequency of monitoring increases as well. Furthermore, the findings show that staging of investments can be placed in an agency and monitoring framework.

Furthermore, as such complexity would have it, Bengtsson (2011) finds that venture capital contracts tend to be highly heterogeneous. Nevertheless, this complexity and heterogeneity is also limited to a certain extent as Kaplan et al. (2007) note: institutional investors who use US style VC contracts in non-US countries report less failed investments, regardless of the level of VC experience. Similarity with US VC contracts is more frequent in common law countries than in countries with alternative legal settings. Overall, the authors find that non-US contracts exhibited less control rights, less liquidation and exit rights, as well as a less frequent use of anti-dilution rights, vesting, and milestones. Due to the higher similarity of common law practicing countries with US style VC contracts, the use of anti-dilution rights, liquidation and vesting rights are found to be more common. The authors identify that institutional investors are more likely to apply US style based contracts regardless of the legal setting of the country they are in with an increase in investment experience. Furthermore, all VCs in the sample who shifted contract form all shifted from the use of non-US style contracts to US style VC 
contracts. The authors explain this behavior through the long-term development of contracts over the past decades of VC activity in the US and the therewith generated contract-efficiency. ${ }^{8}$

Cumming (2005) uses a sample of Canadian investments and finds that a mix of financial instruments mitigates agency related costs. The author notes that, although convertible preferred equity is found to be the prevalent form in the US in prior studies, the Canadian sample uses multiple other forms of securities as well and that convertible preferred equity was not the most frequently used form. The paper posits that there is no single optimal form of security for venture finance. This difference between the US and Canada is partly explained by taxes. Gilson and Schizer (2003) provide an explanation on convertible preferred stock in the US and also in terms of these tax differences unique in the US. In doing so, the authors note that portfolio firms give convertible preferred stock to VCs in order to decrease the tax burden on management incentive compensation - which the authors claim to be a key component of VC contracting in the US. Cumming (2005) also finds that, for the Canadian sample, the type of venture was also influential in the type of security used. For instance, seed stage ventures are more likely to be structured using straight preferred equity than convertible preferred equity. The author posits that this security decreases agency costs amongst syndicate investments. Seed ventures differentiate themselves as well in that debt based securities (straight debt, convertible debt, or even a mixture of debt and common equity) are less likely to be used. This, the author notes, is likely due to the low cash flow of start-up ventures.

Ibrahim (2008) notes on a general level that contracts from VC deals ought to outline the rights and obligations of the VC towards the venture, resulting in information asymmetry which must be mitigated. To protect the investment and to account for the information asymmetry, VC contracts typically include five elements. (1) staged financing, meaning that the funds are given to the entrepreneur in stages. (2) VCs take convertible preferred stock for the capital they provide, different from the common stock that is typically given. (3) VCs exert control over the venture through presence on the board of the venture. (4) Negative covenants also impact the decision making of the venture. (5) VC contracts provide specific rights for the deal's exit, including redemption rights, demand registration rights, and conversion rights. All in all, these contractual elements aim at reducing information asymmetry and the ability of the entrepreneur

\footnotetext{
${ }^{8}$ An alternative explanation could be institutional isomorphism (cf. Bruton et al., 2015).
} 
to act for his personal benefit. These contractual traits are also found by Goldfarb et al. (2014) who note that VCs tend to have more liquidation rights.

In another paper, Kaplan and Strömberg (2004) assess 67 investments by 11 funds by studying the investment memoranda with the aim of understanding the effects of agency related issues on contracts. Their empirical results indicate that internal risks (unknowns between the entrepreneur and the institutional investor) correlate with incentive and control mechanisms and therefore with more control and financing in subsequent rounds by, and for, the institutional investor as well as higher contingent compensation for the entrepreneur. Further, external risks (unknowns to both the entrepreneur and the institutional investor, such as unpredictable market behavior) are also associated with more control for the investor. Here, this risk shortens the time between investment rounds and increases control for liquidation rights by the institutional investor. Through the classification of execution risk (which is a measurement of the risk associated with the venture's dependence on the entrepreneur), their results indicate that typical incentive schemes are less effective in complicated settings. Furthermore, the authors note that about half of the venture capitalists included in their paper expected to have strong influence on the recruiting process of the management.

\subsubsection{Changes in ownership structures}

VC contracts typically involve large amounts of equity being sold, Goldfarb et al. (2014) show that VC-only deals result in $43 \%$ of equity being sold by the entrepreneur in series A financing. Furthermore, Kaplan and Strömberg (2002) find that roughly 50\% of cash flow rights are given to institutional investors, whilst $30 \%$ are retained by the founder and $20 \%$ by others. This is an indication for the changes that the venture undergoes through $\mathrm{VC}$ financing, and these equity stakes are much higher compared to other forms of equity finance. Kaplan and Strömberg (2002) provide a thorough insight into the contractual workings of institutional seed financiers. In their paper, contractual theory is compared to the findings yielded by contracts data collected from 213 investments into 119 ventures by 14 funds. Their findings indicate that contracts allot cash flow rights, board rights, voting rights, liquidation rights, and other control rights separately. Through implementation of these contracts, the control is shifted from institutional investor to the entrepreneur depending on the performance of the venture. Good performance shifts the control to the entrepreneur whilst bad performance shifts it away. Ventures yielding superior performance shift the institutional investor's control to only cash flow rights. Furthermore, in order to retain the entrepreneur, vesting and non-compete clauses are used. 
Their research shows that the use of control rights and monetary incentives serve as complementary rather than substitution. The authors' conclusion implies that, although existing contract theories hold up well in the real world, these theories are overall still underdeveloped and not as complex as the contracts studied in their sample.

Hellmann (1998) uses a theoretical model that analyzes the interaction between VCs and the entrepreneur. The author places particular emphasis on corporate control. Specifically, why an entrepreneur would voluntarily sacrifice their right to hire the CEO. It is found that VCs seek to employ CEOs that are better suited and add more value to the venture. Further, the main finding is that the lower the equity stake and the more wealth-constrained the entrepreneur is, the more investor control the relationship will exhibit. In another theoretical paper, Hellmann (2006) discusses the use of convertible securities in VC contracts. The author notes that convertible preferred equity can play a significant role on cash flow rights. The exit through an IPO or an acquisition is the deciding factor on how these rights are influenced. The author notes that more rights go to the institutional investor during an acquisition than during an IPO and that these cash flow rights may even continue under condition of fulfilling certain milestones.

Cumming (2008) discovers that more control rights as well as veto rights on the side of the capital provider increase the likelihood of an acquisition (30\%), rather than an IPO or a writeoff. In the investigation, the author finds that the right of the venture capitalist to replace the founding CEO is also an influential element in the outcome of the exit. On the other hand, weak control rights are more likely to spawn an IPO or a write-off. Cumming and Johan (2007) also provide evidence that contractual elements can influence the behavior of institutional investors. Adding to these findings, Bengtsson (2011) focusses on the usage of covenants in venture capital contracts. The findings indicate that covenants are nearly always used in institutional investor contracts, regardless of board majority, and may cause conflicts of interest between the capital provider and the capital seeker.

\subsection{Post-investment stage: behavior, growth, and success/failure}

The behavior of VCs in the post-investment stage is more thoroughly studied. Beginning with Gorman and Sahlman (1989) and progressing with a general outline of VC behavior and attributes by Sahlman (1990). Lerner (1995) continues more systematically by studying the representation of VCs on the boards of their portfolio firms. Others, such as Cochrane (2005) 
and Kaplan and Schoar (2005) investigate investment-return based empirics. The studies of this investment stage cover multiple aspects, such as the strategic, management, and governance influence of the $\mathrm{VC}$ on the venture but also the performance of these investments and even post-divestment influences.

\subsubsection{Interactions with the venture}

Lerner's (1995) findings indicate high involvement in the invested venture, as also outlined earlier, being a sign of institutional investors' active investor role. The author's discoveries show that when the CEO of the venture changes, board representation of the VC increases, while other outside directors stay the same. The VC's representation on the board is also linked to the distance between the VC and the venture. These behaviors are different from $\mathrm{VC}$ to $\mathrm{VC}$, however. Rosenstein et al. (1993) find that the quality of the VC is also influential on the behavior exhibited. The authors find that institutional investors who are under the top 20, and lead investor, hold larger board representation in their portfolio firms than others. The quality of advice and value added by VC directors, as rated by the CEO of the venture, is ranked as indifferent to that of outside board members. However, it is ranked superior when these directors come from a top 20 lead institutional investor - non-top 20 lead institutional investors are not significantly different from outside board members. The authors conclude that the quality of advice and value added between top 20 and non-top 20 institutional investors is not noticeably different, though top $20 \mathrm{VCs}$ who lead the investment tend to perform better in terms of perception given by the CEO of the financed venture. The help provide by board members is found to be more influential and impactful in early stage rather than later stage financings. Primary fields of help are found to be in financial monitoring, serving the management team, and recruiting. Furthermore, institutional investors who exit through an IPO stay influential and involved even beyond this event (Barry et al., 1990; Lin and Smith, 1998). Barry (1994) generalizes that a third of the invested ventures typically result in losses whilst a noteworthy remaining portion will result in a write-off of the entire investment.

Gorman and Sahlman (1989) conduct a survey in which they study the interaction of VCs with their portfolio companies. They find that the primary role of a VC is to secure future capital, spending nearly 100 hours per year at the venture's location or communicating through other channels of communication. Additional roles of the $\mathrm{VC}$ are outlined as aiding with the formulation of strategies as well as assembling the management team which is noted by VCs as being the primary reason for a venture's failure. Hellmann (1994) provides further insight 
into the behavioral traits of institutional investors through an assessment of the financial structure and control mechanisms that are applied. Overall, the paper investigates a contractinglinked problem where both the entrepreneur and the VC are incentivized to perform. The author notes that VCs, who invest in particularly high-risk ventures, provide staged financing in order to retain the option to exit a venture at an intervening stage. This method of refinancing gives the VC additional control. Though such staging can produce short-term thinking on the side of the entrepreneur, monitoring practices implemented by an institutional investor allow such problems to be circumvented. Hellmann (1994) argues that, for monitoring practices to be sufficient in solving such problems, a viable equity stake must be obtained by the investor. Under certain circumstances, the entrepreneur may also yield control rights to the institutional investor in order to retain a larger equity stake.

Institutional investors often get involved in the venture in ways of which the consequences have not been thoroughly researched, such as the venture's corporate governance structure and practices. Gray and Nattrass (1993) report that institutional investors replace the CEO in more than $75 \%$ of ventures within the initial 18 months following their investment. ${ }^{9}$ Hellmann and Puri (2002) also find this phenomenon taking place in VC-backed ventures in both the situation of consent as well as when such a change seems antagonistic. Moreover, obtaining institutional financing is linked to the development of more sophisticated human resources, superior hiring policies, such as for marketing positions, and other changes. Bonini et al. (2012) show that funding from a VC influences executive hiring, board decisions, appointments of personnel, incentive schemes, and executive compensation as well - increasingly so the higher the funding amount is. The sample used includes two predominant regions, Europe and the US, and yields that funding is only partially important in explaining this influence of strategy and planning of the venture. These findings differ to European VC-backed firms, where the funding amount only influences CEO hiring as well as investment planning of the venture. The scholars argue that such discoveries originate from cross-country differences of legal systems and culture which affect the implementation of corporate governance depending on the region. The authors also note that these governance practices change with certain factors, such as industry, investment stage, and nationality. The difference of nationality, the authors show, has significant impact on cross-border investments.

\footnotetext{
${ }^{9}$ For more detail, see also Dubocage and Galindo (2014) and their analysis of founder, CEO replacements in VCbacked ventures.
} 
Bottazzi et al. (2008) identify some of these behavioral traits as well and assess them on venture performance. They find that when the VC engages with the selection of senior management, the hiring of outside directors, and raising additional capital for the venture, that the portfolio company's performance is higher. Interestingly, regular communication between the firm and the VC does not contribute towards better performance. This, the authors explain, is probably caused by the passiveness of communication versus the activeness of acquiring personnel and hands-on aiding the venture. These findings highlight the still under-researched field of the effect of human capital on firm performance.

Kaplan et al. (2012) study the characteristics of CEOs and whether their abilities matter by distinguishing upon two factors. The first factor is general ability whilst the second factor are the communication and interpersonal skills with execution skills. The authors find that, for VC CEOs success is more aligned with resoluteness, execution skills, and overconfidence skills than with interpersonal skills. The results still require further research, as the authors indicate that the results for VC CEOs is mixed. This compares to buyout CEOs whose success, in addition to the above findings which are also found for this group of CEOs, is linked to general abilities as well. Whilst accounting for talent and ability, incumbency appears to be unrelated to success.

Cumming and Johan (2007) note that, although cash flow and control rights granted to the VC help the institutional investor advise the venture, these rights do not help moderate conflict between the institutional investor and the entrepreneur. In regards to governance, the empirics show that non-contractual governance systems are equally important to the contractual ones for decreasing VC-entrepreneur conflict and allowing the institutional investor to advise the venture. Conflict is bred, however, when the VC acquires a large equity stake, leading the VC to seek additional monitoring and control and thereby creating possible increases in conflict. More statistical support is found for the effect of VC advisory services when assessing veto rights. The authors examine the effect of veto rights on asset sales, asset purchases, changes in control, issuance of equity, and others, finding that VCs with veto rights offer circa $30 \%$ more advice than institutional investors who are not given these rights. Convertible securities also yield more advice from the VC. The authors highlight the importance of not only cash flow rights, but also of veto rights as incentivizing institutional investors. The security that a VC feels with being an investor in a venture increases with the amount of veto rights it is given. 
These findings clearly highlight the importance of both interpersonal as well as contractual aspects on the performance of a venture. Having discussed the differences in legal settings amongst countries, however, research gaps still exist and investigating these cross-country differences remains underexplored.

\subsubsection{Cross-border influences and investments}

Looking at the post-investment stage, Groh and Bertoni (2014) investigate exit opportunities of venture capitalist investments and how they are affected by supplementary exit opportunities brought by cross-border investors. The authors find that additional M\&A opportunities in the foreign country increase the likelihood of a trade sale whilst the same, yet weaker, effect is found for IPOs. Conclusively, a suboptimal local exit market can, at least to some extent, be compensated by cross-border investors and foreign financial markets. This finding is somewhat reflected by Devigne and Manigart (2013) who investigate investment strategies of crossborder venture capitalists. The findings indicate that these cross-border investors are more likely to invest in another country when there is the potential to invest alongside local partners who are more experienced in the market as well as in larger sized deals. Such behavior would indicate the willingness to extend venture capital networks into other countries, thereby increasing the potential exit market. In a more recent study, Devigne et al. (2016) investigate

the differences between domestic and foreign VC investments in terms of an escalation of commitment framework. The authors find that, even when co-investing with a local partner, cross-border VCs are more efficient at divesting an unsuccessful venture. Cross-border research also leaves room for the investigation of $\mathrm{VC}$ networks on divestment opportunities.

The behavior of VCs in the cross-border setting have also been explored by Bruton et al. (2005) using institutional theory. In doing so, different behavioral traits of VCs in different countries can be explained through (1) normative, (2) regulatory, and (3) cognitive institutions (Scott, 1995). Scott (1995) defines normative institutions as ones which possess norms and values that serve as a means of achieving a defined objective. The second, the regulatory institution, is defined as one which sets rules, monitors, and applies sanctions. The third, the cognitive institution, is based on differences in culture. This institution plays a role in how information is prioritized, retained, and memorized. Using this theory, Bruton et al. (2005) explain the adaptation of the US VC industry in Europe, stating that through the training that European VC funds received by US VCs (or VC funds that are founded by former US venture capitalists), 
the norms and values are passed on. However, such adaptations are never absolute, as highlighted by Wright et al. (2002).

Wright et al. (2002) investigate the behavior of US venture capitalists in the Indian market. The actions of these institutional investors adapt to the local market behavior. In terms of the second institution, countries' jurisdictions vary. Legal differences, such as common versus civil law, are relevant to VCs (see La Porta et al., 1998, 2000, 2006). Cumming and Johan (2007) find that VC-entrepreneur conflict is eased when the entrepreneur's country has a higher quality legal system in place. These differences may account for superior investor protection for the $\mathrm{VC}$, as it is supposed to be the case with common law practicing countries. However, as noted by Bruton et al. (2005), it is also the enforcement of laws that play a role. The nonlegal, yet regulatory differences, are also reflected by the established financial markets. Black and Gilson (1998) identify this difference as follows: a country can either be bank-centered or stock market-centered. Such differences in market structure shows that stock market centered economies are more attractive for institutional investors than bank-centered markets. On the cognitive level, one example of variance between countries is the regard for entrepreneurs. In the US, entrepreneurs are seen in a positive light by society. This compares to other countries and even entire regions, such as Europe and especially Asia (Bruton et al., 2005). The differences amongst countries in these three categories provide possible reasons for $\mathrm{VC}$ decision making. Further, they mark future research potential in addition to the paths of identifying economic and agency theory related reasons for VC decision making. Research on this remains light, however.

Some important literature focuses on the legal differences between countries. Cumming et al. (2006) study the influence of legality on VC exits. The authors find that countries with high legal index also increase the likelihood of more IPOs. Further, legal system quality is a stronger indicator for VC-backed IPOs than an active stock market (as argued by Black and Gilson, 1998). These legal qualities are noted to decrease agency conflicts between the outside shareholders and the entrepreneur. Stock market size, however, is found to be strongly associated with a country's legal index. The conclusion, therefore, is that legal quality facilitates exits and fosters active VC funding and these appear to be highly correlated with active stock markets. Also relevant is Lerner and Schoar (2005) who find that transactions vary according to legal enforcement. The authors show that countries which exhibiting more legal enforcement also provide environments that foster higher valuations and returns. 
In regards to differences amongst targeted countries, Sapienza et al. (1996) find that between institutional investors in the US, the UK, the Netherlands, and France, the prioritization of VC roles was ranked identical across these countries. Strategic involvement is ranked first whilst mentoring and networking is ranked second and third, respectively. The authors do find differences between these countries, however, in terms of the involvement as well as the added value. US and UK VCs are found to be the most involved in their portfolio companies, also yielding the highest added value. Of the four countries, French VCs are found to be the least involved, also yielding the least added value to the portfolio firm. The authors note it is ventures which are already outperforming the market that the institutional investor is most able to add value. Another set of circumstances in which VCs are most capable of adding value is in highly uncertain situations, such as early stage investments or high-technology start-ups, as well as when the $\mathrm{VC}$ has industry-relevant knowledge. These attributes positively impact the institutional investor's ability to add value to its portfolio firms.

Cumming and MacIntosh (2003) investigate partial exits in the US and Canada. The authors show that with the increase of information asymmetry between the seller (VC) and the buyer, the likelihood of a partial exit also increases. The rationale of a partial exit lies in signaling quality. The data also indicate that the VC industries between the US and Canada are different and that cross-country exits are influenced by legal and institutional settings.

\subsubsection{Investment durations and exits}

Gompers (2005) investigates, amongst other factors, the influence of portfolio ventures' assets on the investment duration. The author finds that when industry ratios of tangible assets to total assets are high, market-to-book ratios as well as R\&D efforts are lower, the duration of the investments is found to be longer. Furthermore, ventures that receive more capital and funding rounds are found to be more likely to IPO, compared to being sold or written off. Also, the right timing is influential on successful IPOs is the timing. Lerner (1994b), who investigates the ability of VCs to time their portfolio firms' IPOs on a sample of biotech ventures, notes that more experienced institutional investors are more capable of finding the ideal time to take their portfolio ventures into an IPO as measured by higher valuations and market peak times. VCs act on market peak times through multiple ways in their pursuit to execute the IPO of a portfolio company. These include board seats and control rights but also, and perhaps more importantly, through their advising role to the venture's management. This advising role is 
strong for IPOs due to the VCs experience in taking firms public. Other factors are also influential in terms of VC-backed IPOs. Bock and Schmidt (2014) find that VC characteristics as well as fund dynamics have impact on exit decisions. These characteristics and dynamics include the fund manager's reputation for limited partners, which, if lacking, more likely leads to a partial exit. The finite lifetime of $\mathrm{VC}$ funds also creates scenarios which are not always value maximizing (see also Kandel et al., 2011 who show that the interest alignment between LPs and GPs can be askew due to the information inefficiencies between the two). Bock and Schmidt (2014) show that funds which are nearing their end will more likely choose a full divestment. The differentiating behavior between first-time funds and repeat-funds is also studied and the authors show that first-time funds retain shares longer than funds satisfied with their performance.

Cumming and MacIntosh (2001) assess the investment duration of VCs in the US and Canada. The authors find support that VCs in the US use the early investment stage to rid themselves of lesser portfolio companies, finding that the investment duration for firms in the early stage of development is typically shorter. Furthermore, the increase of capital available to the VC industry further shortens investment durations for VCs in the US. The authors find that differences between the US and Canada are high in terms of VC investment durations. This is explained by lower levels of experience of Canadian VC fund managers as well as regulatory and market differences.

Even after a successful exit by a VC, traits of this former investment are maintained. Some of these are the duration that the venture remains on the stock exchange or also the governance structures and monitoring practices it pursues. Gill and Walz (2013) find that VC-backed ventures funded by reputable and experienced VCs that went public remain at the public stock exchange for a shorter time than non-VC-backed ventures. The authors note that this could be explained by signaling, given the reputation and experience of the $\mathrm{VC}$, and the IPO of VCbacked venture therefore indicates a temporary state, given a delayed trade sale. Similar findings are reported by Nahata (2008) who writes that reputable VCs tend to divest sooner and are more likely to have a successful exit. Audretsch and Lehmann (2004) show that even in bank-centered markets such as Germany, VC-backed ventures generate superior performance to non-VC-backed ventures. These growth rates of VC-backed ventures, the authors note, are also evident post-IPO. 
When looking at the governance structures of ventures and their levels before and after divestment, Campbell and Frye (2008) find that VC involvement, VC quality, and the undergone divestment form produce noticeable differences on the ventures' governance systems compared to non-VC-backed ventures. Regardless of quality of the VC, VC-backed ventures exhibit more monitoring than non-VC-backed ventures. When including VC quality, evidence shows that high quality VC-backed ventures maintain much more stringent monitoring practices compared to their low-quality VC-backed counterparts. The authors find that this difference fades over time. Following the IPOs, VC-backed ventures decrease their monitoring levels, whilst non-VC-backed ventures increase them.

\subsubsection{The effects of syndication}

Casamatta and Haritchabalet (2007) evaluate the effect of syndication on post-investment performance, finding that syndication has costs. The authors identify these costs as follows: (1) The first cost resides on the principle that syndication occurs in order to share the burden of information gathering. Bygrave (1988) argues that institutional investors manage information asymmetry and uncertainty through information gathering which can be facilitated through coinvestments. However, syndication has the potential of lowering the profits of the initial institutional investor who discovered the deal due to the sharing of this future profit, prompting suboptimal information gathering and learning due to decreased incentives. Casamatta and Haritchabalet (2007) show that this cost increases with the experience of the first venture capitalist. (2) The second cost that may arise from syndication lies in the sharing of ownership of the venture. Sharing this venture results in less effort as a result of moral hazard. This cost, contrary to the first cost, decreases with the level of experience by the first investor.

\subsubsection{Returns on investment}

Also part of the post-investment stage is the return on invested capital which Manigart et al. (2002) look at with focus on VCs in five countries. The authors find that VCs which focus on early stage finance demand higher required returns than VCs that focus on later stage finance. The same is the case for VCs who are diversified in terms of the chosen investment stages, as this diversity is not interpreted as a risk minimization measure. More numerical analyses are performed by Cochrane (2005) who studies expected returns, standard deviations, alphas, and betas of institutional investors' investments. Empirics show that later round funding is associated with less risk and a higher probability of going public, though the chances of an 
acquisition and total loss remain equal to earlier round financings. The industry of the venture has no noticeable effect on the potential outcome, IPO, acquisition, or failure.

Kaplan and Schoar (2005) also investigate the returns of VC funds as well as LBOs. Average fund returns, netted of fees, perform about equal to the S\&P 500. When not looking at netted of fees but gross of fees, both types of funds outperform. Weighted by committed capital, institutional investors perform superior to the S\&P 500. Their findings also show that high performing funds are more likely to raise a subsequent fund and that outperforming general partners are likely to outperform again in the future. Furthermore, underperforming general partner funds are likely to underperform again in the future. Additionally, after times when the industry performs above average, the amount of new partnerships increases. These new funds, however, that are raised during peak periods, are less probable to raise a new fund after and empirics show that these funds perform below average. The authors note that when many new funds are raised, it is the new funds' poor performance that affects (negatively) the overall industry performance. Fund size and general partner experience are indicators of better performing funds, with the effect of fund size being concave. The authors conclude by raising the question of the effect of governance practices being tied to the performance of general partners and the reason why, during peak periods, funds are not directed to the best general partners but end up with funds that perform below average.

\subsection{Conclusion and theoretical trends over time}

In order to tie these empirical investigations together and to provide an evolutionary insight on the theoretical level, we provide an intermittent section-based conclusion at this point. The framework depicted in figure 1 allows us to add value to this process by differentiating the aforementioned investigations into two general theoretical approaches: (1) monitoring and interest alignment and (2) cognition, knowledge, and skill elements. The relevance of this differentiation, and the conclusions that can be drawn from it, reside in the understanding of VCs gained therewith. In other words, each of these factors - whether it is investigating the monitoring practices or the interest alignment of VCs and their portfolio firms, or the cognition, knowledge, or skills shared and implemented between and by these two - furthers our knowledge of venture capital. Furthermore, some of these components are investigated more thoroughly than others in the existing literature. It must be noted, though, that regardless of this they share some overlap. For instance, they are not exclusive to an investment stage and they, even if not explicitly investigated, exist and influence each other. In other words, even though 
the cognitive component is only more recently acknowledged in the literature, it does not mean that this component did not exist decades ago and that a person's cognitive component does not influence that person's principal-agent conflict. These components are therefore key in tying the literature together and more importantly pointing out how research has shifted - rather than on a historical level, seen in a preceding section, on a theoretical level.

Overall, in terms of $\mathrm{VC}$ research, monitoring and interest alignment have been studied more thoroughly or at least for a longer time. In part because these two components can be investigated regardless of the investment stage. Though monitoring and interest alignment are more prevalent in the investment and post-investment stages, elements can also be found in the pre-investment stage (such as the approaches to deal-flow origination, looking at the reasons of a venture choosing a $\mathrm{VC}$ over another potential capital provider and the alignment of interest between co-investors). Furthermore, Jensen and Meckling commenced this pursuit of research back in 1976 which shows to what extent this theoretical concept has been established, given that it is still in use today. To some degree, the same applies for the skills component. VCs' skills are being examined in all investment stages. For the pre-investment stage, scholars pursue the understanding of skills that VCs use to generate deals (e.g. Tyebjee and Bruno, 1984), in the investment stage, for instance, Kaplan et al. (2007) show the skills attained through contract efficiency, and in the post-investment stage Lerner (1994b) is an example of a scholar who shows the VCs' skill of optimally timing the exit of an investment. The effect of cognition and knowledge, however, is less prevalent throughout the literature up to date.

Cognition and knowledge are, to some extent, more recent, more subjective, and certainly much more heterogeneous amongst its users. This makes them more difficult to study in a controlled and empirical environment. Cognition, which has primarily been picked up by Bonnet and Wirtz (see Bonnet and Wirtz, 2011, 2012; Bonnet et al., 2013; Wirtz, 2011), has not yet reached thorough levels of investigation and understanding due to the complex environments it can be investigated in (individual investments versus co-investments, both simultaneous and sequential; VCs versus BAs; etc.). Cognition, which has been introduced as an add-on to agency theory, has not been thoroughly studied on the financial level of individual venture capital investments (for instance how the cognitive component of actors impacts the return on investment of VC investments). Further, the cognitive differences between VCs and entrepreneurs have not been found to have been studied in a VC-dedicated investigation. Though studies exist that investigate VC behavior which relate to decision-making behavior 
and other cognitive features ${ }^{10}$ these studies only identify that VCs hold roles as advisors and this role is mostly traced back to monitoring and control frameworks but not the cognitive component, as it would be analyzed in the strategic management literature. Knowledge has been investigated to a certain extent, but its conceptual underpinnings remain understudied in the empirically driven entrepreneurial finance literature. One element under which knowledge has been touched upon is the sharing of information amongst VC networks (Bygrave, 1988; Hochberg et al., 2015) and how the experience of these investors affects investment behaviors (Hochberg et al., 2007; Khavul and Deeds, 2016; Lerner, 1994a).

Using the framework depicted in figure 1, we can therefore argue that monitoring and interest alignment remain the primary components of $\mathrm{VC}$ related investigations. Though traces of cognition and knowledge are starting to be investigated (in terms of advice and counsel or information sharing and decision making), these are mostly researched in relation to their monitoring and interest alignment purposes.

\footnotetext{
${ }^{10}$ Gorman and Sahlman (1989), who study the influence of VCs on portfolio firms, primarily focus on the hours spent communicating with the portfolio firm, the role as a builder of the firm's management team, and formulating strategies (see also Bonini et al., 2012; Cumming and Johan, 2007). These studies, however, tend to focus more on the monitoring, controlling, and interest alignment elements of such behavior, rather than the cognitive or knowledge components.
} 


\section{Business angels}

This section is dedicated to past, present, as well as future research potential. It is structured to provide an understanding of this financial mechanism in terms of past development in the market by beginning with a definition and characteristics. After, we will outline BA research development since its inception, discussing thematic hotspots. Subsequently, the three stages, as outlined in the framework introduced earlier, will be covered. Following these sub-sections, we provide a brief conclusion, revolving around the theoretical evolution of BA research, that seeks to tie in the reviewed literature with the theoretical framework presented in the introduction.

\subsection{Definition, relevant markets, and general characteristics}

Business angels are high net worth individuals who are accredited investors investing private wealth, usually between USD 10,000 and USD 250,000, for their own reasons into a venture that is, typically, local, unlisted, and without a family connection to the business angel (Agrawal et al., 2014; Berger and Udell, 1998; Bonnet et al., 2013; Capizzi, 2015; Hornuf and Schmitt, 2016a; Leavitt, 2005; Morrissette, 2007; Politis, 2008; Prowse, 1998; Wetzel, 1983, 1994). Angel investments are commonly structured using equity contracts in the form of common equity (Berger and Udell, 1998; Wong et al., 2009) with convertible preferred and preferred equity ranking second and third (Wong et al., 2009). Business angels play multiple major roles besides being a provider of financial capital. Business angels also provide strategic input, monitoring and control (however, less formal than an institutional investor), as well as adjoining their professional network. These investors often take positions on the board of directors or become consultants to the ventures (Freear et al. 1995; Hindle and Lee 2002; Landström 1993; Mason et al. 1991; Mason and Harrison 1996; Politis, 2008; Prowse, 1998; Tashiro 1999). Furthermore, business angels maintain close interactions with the venture in order to both endorse and safeguard their investments. Business angels can also be former entrepreneurs or at least have had a career in management (Aernoudt 1999; De Clercq et al. 2006; Ibrahim, 2008; Politis and Landström 2002; Politis, 2008; Prowse, 1998; Wetzel, 1983) who contribute their contacts as well as know-how related to entrepreneurship and management (Bonnet and Wirtz, 2011; De Clercq et al. 2006; Lumme et al., 1998; Mason 2006; Politis, 2008; Wetzel, 1983). Angel investors, however, are found to be a highly heterogeneous community and also pursue varied processes when investing into start-ups (Croce et al., 2016b; Freear et al., 1994; Lerner, 1998; Mason et al., 2016; Wetzel and Seymour, 1981). 
Wetzel $(1983,1987)$ notes that the informal venture capital market is not transparent and yields numerous unanswered questions. The author indicates that, based on data at the time, the informal capital market was twice the size of the formal venture capital market, citing that the amount of ventures financed by informal capital providers was ten times as many. The number of individuals upholding this position as an informal venture capital provider is significant and deserving of our attention - as is the understanding of their roles. Prowse (1998) also notes the informal venture capital market size to be significant, adding that, though this market is opaque, it is found to be heterogeneous and localized.

Summarizing the added value roles of a business angel, Politis (2008) categorizes these into four: (1) sounding board/strategic role, (2) supervision and monitoring role, (3) resource acquisition role, and (4) mentoring role. The author defines these four roles by reviewing 14 publications on business angels and their various forms of adding value. The first (1) identified role outlines that a business angel provides strategic input reflecting the angel's management and business experience. This includes amassing resources, providing reflection on ideas, and giving advice on the manner, as well as the timing of, created value realization (Politis, 2008). The second (2) role is noted as the efforts made to protect the investment from managerial wrongdoing. It is in this role that Jensen and Meckling's (1976) agency theory is integrated into the role of a business angel. Here, two problems are created: (1) that information can be disseminated asymmetrically and (2) the agents may abuse rights in order to foster their own utility maximization. Jensen and Meckling (1976) note that information asymmetry causes conflicts as the agent may not act in the interest of the principal due to his utility maximizing behavior. Controlling for such behavior requires monitoring and bonding, which creates costs. These two underlying methods attempt to minimize information asymmetry and enhance interest alignment and subsequently lower the costs which harm the creation of value. The third (3) role is integrating the value of the business angel's personal network, consisting of professional contacts within the industry. This network can facilitate investor talks, supplier talks, as well as raising additional capital (Politis, 2008). The fourth (4) and final role is mentoring which involves the experienced business angel and the less experienced entrepreneur. This role provides mental support or sharing the burden in difficult times with the objective of stabilizing the venture and providing a successful future (Politis, 2008). 


\subsection{Research trends over time}

Contrary to formal venture capital research, informal venture capital research remains - to this day - somewhat more elementary and certainly more opaque. One trend that is noticeable in this area of research is the shift from single business angel investments to syndication and business angel network investments. This is interesting to note, and could be explained by increasing data availability on tracking multiple business angels and their networks. Wetzel (1983) notes in the early 1980 s that $60 \%$ of respondents in the survey conducted during the study participate in co-investments during larger transactions. However, much research conducted in the meantime (1980-2010) relates to business angels as individuals rather than groups or networks. This supports the notion that data on these groups and networks is becoming more obtainable.

Another relevance to these developments are the sources used throughout literature as well as its overall progression. Most data that is numerical in nature either comes from open sources (e.g. CrunchBase, see Werth and Boeert, 2013) or from surveys - with most others being qualitative and using interviews or case studies (see e.g. Bonnet and Wirtz, 2012; Bonnet et al., 2013; Mason and Harrison, 2002; Wetzel, 1983). Over the more recent period, unique and hand-collected data, however, is found in some publications (see e.g. Bonini et al., 2016; Capizzi et al., 2016). These researchers use a dataset based on the Italian Business Angel Network (IBAN).

In terms of the overall progression of business angel related investigations, they can be distinguished into three forms. These three forms include pursuit of understanding of or between the individual BA, the formal VC, and BANs. BANs (business angel networks) are formal organizations in which business angels interact with entrepreneurs and invest in selected ventures (individually or in groups). The study of individual angels (non-BAN members) versus BANs (business angel networks) is the third and latest phase of research. Within this topic, many questions endure and it also remains to be seen how results from samples from different countries or regions will compare. The second step in the business angel research progression is the differentiation between formal and informal venture capital. This includes the differences between BAs and VCs but also their interactions and complementarily. The first stage is the identification of BAs and how they act in the market. 


\subsection{Pre-Investment stage: deal-flow, selection, and evaluation}

Business angels did not receive the attention of researchers who, in turn, did not begin to empirically cover their investment processes until recently. The literature that is available shows that the understanding of this field is still ongoing and requires more research in regards to the implications of this investor type. In other words, the behavior of informal venture capitalists, whether acting individually or together, remains underexplored in the preinvestment stage, partly due to the heterogeneity of these investors. Further, literature notes that this differentiation between individual and co-investments is vital as the processes applied by individuals is distinct from those of groups and networks (Croce et al., 2016b; Mason et al., 2016). In this section, we provide an overview of this research and identify research gaps.

Until a few years ago, only a three-stage model outlined the business angel investment stages: search, negotiation, and post-investment stages (Amatucci and Sohl, 2004). Riding et al. (2003) and van Osnabrugge and Robinson (2000) each establish eight-stage models, however, none of the three models are based on empirical foundations. Paul et al. (2007) are the first to outline a five-stage model based on empirical findings. These five stages are (1) familiarization, (2) screening, (3) bargaining, (4) managing, and (5) harvesting. This framework includes possible back-step procedures in case a reassessment is needed and provides intricate insight into the complex workings of such investments. Furthermore, it disentangles the formal and informal networks involved in the process. Formal networks would primarily be BANs whilst the informal side would include co-investments by other business angels. These details are important to note as much of literature focuses exactly on these differences (such as formal versus informal networks). This only recent research shows how elementary business angel research still is and how under-researched each stage, such as the deal-flow and venture evaluation stage, is. Further, as pointed out by Mason et al. (2016), these stages are different, and more complex, for BANs. This prompts not only an analysis of how informal venture capitalists are different from the formal venture capitalists (a primary differentiation made in most papers - see e.g. Bonnet and Wirtz, 2012; Goldfarb et al., 2014; Morrissette, 2007) but also how informal venture capitalists are different when acting individually versus in groups or networks (see Bonini et al., 2016; Croce et al., 2016b).

\subsubsection{Benefits of BAN membership}

Kerr et al. (2014) assess informal venture capital financing of ventures and, although their paper focuses on the post-investment stage, the authors identify five benefits of angels being 
network members. (1) by combining their individual investments, the deals generally accumulate larger amounts, and (2) through this accumulation, these deals enable angels to diversify and spread their investment risks over more investments. (3) economies of scale produce lower due diligence and legal costs, and (4) as a BAN is more easily discovered by the entrepreneur's search than an individual, they have the possibility of producing more attractive deal-flow. Lastly, (5) these networks have a higher likelihood of including more experienced angel investors. These are general remarks regarding BANs, however, they provide important insights. Another such insight is provided by Mason and Harrison (1997) who discuss the traits of BANs. The authors find the common occurrence that BANs are local, not-for-profit organizations in nature. It is noted that an increasing amount of privately created organizations are on the rise. However, a demand for both, public and private, types of organizations exists in the market. Furthermore, literature identifies that BANs exist with specific focus on industries or also other unique traits, such as BANs specifically for women (Mason et al., 2016).

Empirically, Bonini et al. (2016) investigate the investment choice of BAN and non-BAN angels using a unique set of 625 business angels and over 800 investments. The authors find that being a member in a BAN provides valuable information as well as superior networking opportunities and monitoring whilst also reducing risk - compared to when a business angel acts independently. In contrast to angel network members, Bonini et al. (2016) find that for non-BAN business angels, the unwillingness to be an active investor relates negatively to the amount of capital provided. The authors conclude that business angels acknowledge the advantages provided by BANs. Wetzel (1983), already in the 1980s, notes that angels use each other as well as friends and business associates as sources of deal-flow. Given the lack of data availability, however, such research is resurfacing again in recent years, seeing as Bonini et al. (2016) use data from the Italian BAN that also includes unaffiliated business angels. Therefore, business angel research is frequently seen to replicate itself, though, using new datasets for a different region (i.e. Mason and Harrison focus on the UK, Bonnet and Wirtz focus on France, Capizzi focuses on Italy).

\subsubsection{Factors and determinants influencing the investment decision}

Looking in more detail at the entrepreneur-investor criteria and aspects of successfully pitching a venture to business angel network members, Carpentier and Suret (2015) study these investment decisions, stating that experience of the entrepreneur matters indirectly and that 
ventures should ideally establish a management team that has industry knowledge. Another reason for rejection from angel network members, the authors find, is that entrepreneurs are not well enough versed in the goings-on of angel investment procedures. The growing heterogeneity of investments also creates a split between angels investing individually and angels investing as a member of a network, indicating that future research ought to distinguish between these two settings explicitly.

Conceptual discussions on business angels also add theoretical knowledge and ideas when looking at BANs. These papers focus on the benefits and advantages of certain behavioral traits. Leavitt (2005), for instance, notes that, in forming associations and networks, business angels do not only share deal-flow but also other resources, such as accountants and lawyers. In general, research conducted thus far shows that BANs provide a channel of communication for the informal investor and the capital seeking entrepreneur, thereby decreasing costs related to information and search (see Mason and Harrison, 1997). In a theoretical paper, Hellmann and Thiele (2005) show that as search costs accumulated on the side of the BA increase, it leads to fewer BAs entering the market, resulting in fewer early stage deals which also receive lower valuations, consequentially. The search costs on behalf of the entrepreneur, as a result of fewer BAs entering the market, contribute to these lower valuations.

In terms of determinants for business angel investments, Croce et al. (2016b) find that ventures proposed by institutional investors are more likely to successfully navigate the business angel's pre-screening process. Moreover, business angels appear to take significant interest in the entrepreneur and the management team during the subsequent screening stage as these elements are often the reason for rejection. Capizzi (2015) also finds that the management team is the most vital aspect that business angels look at when deciding into which venture to invest, followed by market growth potential. Wetzel (1983) identifies the reasons for rejecting a venture to be a lack of belief in the management, an unsatisfying price, or naïve thinking of the entrepreneur in regards to the product or market. These findings are repetitively discovered: Prowse (1998) also notes that angels reject proposals due to insufficient information about the entrepreneur or an unsatisfying comfort, also naming pricing issues or growth potential as rationales for declining an investment. Furthermore, Goldfarb et al. (2014) find that when comparing the objectives of business angels to those of entrepreneurs and institutional capital providers, business angels are more aligned with the objectives of the entrepreneur than the institutional investor (this is also noted by Bonnet and Wirtz, 2012). The relationship between 
the angel and the entrepreneur is also reflected by other research and it is of interest to note the findings of Balachandra et al. (2014) who show that when an entrepreneur seems to be similar and likeminded to the $\mathrm{BA}$ during the pitch presentation, the $\mathrm{BA}$ is more likely to like the venture. The same behavior on the part of the BA can be observed if the entrepreneur appears to have a positive attitude towards coaching and mentoring.

\subsection{Investment stage: ownership structure and contracting}

Business angel investments can be categorized into four forms of investing: (1) individually, (2) with other business angels (co-investments or through BANs), (3) with crowdfunding investors, and (4) with institutional investors. Provided the heterogeneity of business angels and the aforementioned differences between individual BA and BAN investments, each of these forms can represent a different ownership structure as well as different contractual styles. The amount of research performed in this field is minimal and the findings that have been published may also still be distorted by regulatory heterogeneity between countries.

\subsubsection{Individual investments}

When business angels invest in a venture, the BA ownership structure typically reflects a small amount of equity. This is different from the mindset of VCs who are the eligible subsequent investors and who wish to see majority of equity retained with the entrepreneur until this point (Hellmann and Thiele, 2015; Wetzel, 1983, 1987). Goldfarb et al. (2014) note that, for their specific sample, the entrepreneur retains majority ownership before a series A finance round. In their data, BAs hold an average of $7.6 \%$ of common share equity, compared to $89.5 \%$ by the entrepreneur.

In terms of contracting, when BAs invests individually, Goldfarb et al. (2014) find that deals are much less stringent on cash flow matters, showing that no investment that was investigated in their sample accounted for cumulative dividends and only a few that accounted for provisions of redemption rights. The deals, they note, are overall more friendly towards the entrepreneur. This is in line with literature stating that BAs are more closely aligned with entrepreneurs (Bonnet and Wirtz, 2012; Ibrahim, 2008). Ibrahim (2008) finds that BAs frequently invest for non-financial reasons. As the capital invested originates with the BA, there is no one to report to for the rationale of the investment, unlike VCs. This, Ibrahim (2008) argues, is a reason for less stringent contracts that are thus more aligned with the entrepreneur. Wong et al. (2009) find that common equity is the most frequently used form of investing for 
BAs, with larger deals using more complex forms. Furthermore, BAs do not follow the same approach towards contracting as VCs. In other words, investments are not staged, board presence is found in less than half of funding rounds, negative covenants are rare, and specific exit rights are usually not given. The overall nature of contracts with BAs are heterogeneous and require further research, however. Prowse (1998) notes that the contracts of BAs vary significantly depending on the level of experience of the BA. The author finds that, though these governance mechanisms are less stringent than those of more formal investors, BAs often hold majority voting rights and are seated on the board of directors. ${ }^{11}$

\subsubsection{Co-investment structures}

When BAs co-invest as a group, Ibrahim (2008) finds that contracts are closer in style to those of early stage VC contracts. This resemblance is explained by the characteristics of these deals. These include larger amounts, later stage ventures than when a single BA invests, and more uncertainty caused by the relationship with more than one BA, which results in a surplus of information asymmetry that needs moderation through contractual means. The MIT Entrepreneurship Center (2000) finds that these contracts therefore include rights such as demand rights, voting rights, registration rights, anti-dilution provisions, and information rights.

\subsubsection{BA and crowdfunding contracts}

For the combination of BAs and crowdfunding, specifically equity crowdfunding, not much research exists and the role of the business angel in this field is still being debated (see Ahlers et al., 2015; Brown et al., 2015; Hornuf and Schmitt, 2016a). The contractual implications, however, are that the BAs agree to the same contract as every other investor of an equity crowdfunding campaign regardless of the invested amount (Klöhn et al., 2016).

\footnotetext{
${ }^{11}$ The different findings of Wong et al. (2009) and Prowse (1998) in terms of board representation is one example of how different samples bring about different understandings:

"Sahlman (1990) finds board seats are typically allocated to venture capitalists as part of a financing round. This is not the case with angel investments. Board seats are granted in less than half of all funding rounds." (Wong et al., 2009, p. 224).

"The most important is representation on the Board of Directors. Angels are very often on the board." (Prowse, 1998, p. 790.
} 


\subsubsection{Co-investments with formal venture capital investors}

When BAs invest with institutional investors, Goldfarb et al. (2014) find that control rights are much weaker, including liquidation rights. Further, BAs invest smaller amounts and obtain weaker control rights than institutional investors (Goldfarb et al., 2014; Ibrahim, 2008; Wiltbank and Boeker, 2007). These traits are explained by Ibrahim (2008) who argues that less control and simpler contracts provide less of an obstacle for future $\mathrm{VC}$ investments due to a less complex nature of the venture. The simplicity of BA contracts is also promoted by the behavior that BAs exhibit, namely that they actively monitor and get involved with the venture, therefore not requiring the contractual oversight that VCs ask for. Lastly, the costs accumulated by lawyers would also decrease the efficiency of a BA deal.

\subsection{Post-investment stage: behavior, growth, and success/failure}

In terms of the five stages of the investment process as outlined by Paul et al. (2007), Politis (2008) finds that the post-investments stage, where business angels and their added value in investments is observed, is the most under-researched of the stages for business angels. Recent literature, however, has begun to uncover some findings related to the post-investment stage.

\subsubsection{Influential factors: experience, partnerships, divestment form}

Croce et al. (2016a) find that ventures with funding from BAs who are experienced in early stage investments are more likely to receive subsequent funding, including funding from VCs. On the other hand, receiving funding from BAs with experience in later stage investments increases the likelihood of success (measured by IPO or acquisition) whilst the need for VC funding declined. Co-investments between BAs and VCs are found to produce larger ticket sizes, subsequent VC funding rounds, and a higher probability of IPO or acquisition. These findings have significant implications for entrepreneurs who are seeking external equity funding as a differentiation amongst BAs in terms of experience may yield alternatives to VC funding. Kerr et al. (2014) discover that ventures receiving capital from BAs have a higher probability of success for the four years following funding, experience more expedient growth (as measured through web site traffic), as well as an increased likelihood of receiving subsequent funding from outside the given angel group. When applying a regression discontinuity approach to consider unobserved differences between the examined firms that received funding and those that did not receive angel financing, results are maintained except for the subsequent funding round. The authors note that this difference may be influenced by the time period under investigation and that angel-funded ventures grow with subsequent 
funding rounds as a side-product, influencing venture success in perhaps other ways than it was measured in this study.

Capizzi (2015) finds that business angels increase their IRR (internal rate of return) if the investment is held for more than three years, suggesting that it is in a business angel's interest to hold on to his investment for longer. The author also finds that the exit strategy plays a significant role in determining the IRR of business angel investments. In his paper, he assesses five exit types: (1) closed activity, (2) buy-back from the management team, (3) sale or acquisition to another firm, (4) a sale to other investors, as well as (5) an IPO. The empirical analysis suggests that the buy-back option is the ulterior option of the five, after all others have failed, as it returns the lowest. The sale or acquisition to another firm shows a relationship between exit strategy and a positive IRR. Furthermore, of the five strategies, only the closed activity returns a negative coefficient. Additionally, Capizzi (2015) finds that the level of experience exerted by a business angel on the IRR is in the form of an inverted U-shape. In other words, experience (measured by the amount of investments performed in the BAs life) will positively impact the IRR of an investment to a certain level, after which the experience actually decreases the IRR. The author attributes this phenomenon to overconfidence. Furthermore, the findings note that investments held for longer than three years also produce higher IRRs. Moreover, more selective business angels generate higher IRRs in the investments that they do ultimately invest in.

These results are partly reflected by Mason and Harrison (2002). Using a sample of 127 UK BAs exiting 128 investments, the authors find that $34 \%$ of BA exits are at a total loss, with $13 \%$ being at a slight loss or around zero return, and with $23 \%$ showing an IRR of $50 \%$ or more. The authors further discover that most investments are held for 4 years and divested through trade sales. The success story investments are typically those which receive large follow-up investments, are composed of co-investments, or belong to the category of an MBO (management buy-out). The performance of deals that raise subsequent investments are investments receiving 100,000 pounds or more. Another insight provided by the authors is the deal participants. Under co-investments, other deal participants are, most often, other business angels. For $28 \%$ of the deals in the sample, however, institutional investors invest alongside of the BAs. In their study, whilst BAs invest slightly over 4 million pounds, other co-investors invest nearly 200 million. The authors conclude that business angels focus more on identifying and investing in ventures that will not induce great losses, rather than focusing on finding 
ventures that are 'one in a million'. ${ }^{12}$ This compares to the mindset of VCs, who seek to identify success stories. Furthermore, if the investment is a co-investment with an institutional investor, and the time of the exit does not meet the objective of the institutional seed investor, he will be reluctant to exit. These differences in objectives do not only include the investment duration, all of which can lead to conflict or also to growth.

\subsubsection{Co-investments}

Bonnet et al. (2013) find that strong entrepreneurial growth rates are supported when business angel and institutional seed investors co-invest, drawing on their cognitive similarities. Even though this may be the case for growth, it is generally acknowledged that business angels and institutional seed investors have different objectives (Mason et al., 2016; Stevenson et al., 1987). Furthermore, empirical work shows that conflict between the business angel and the entrepreneurial team leads to a negative impact on the innovativeness of the venture (Collewaert, 2008). Bonnet and Wirtz (2012), however, also indicate that heterogeneity between parties on a cognitive level can result in learning and thus in growth of a venture and the relationship between parties. Overall, this cognitive heterogeneity is lower between BAs and entrepreneurs, as these two parties are more closely aligned. When these two parties add a $\mathrm{VC}$ to the investment round, the dynamics of their cognitive interaction and potential mutual learning become more complex (Bonnet and Wirtz, 2012). These relationship dynamics are capable of being leveraged in order to expedite the growth of a venture (Bonnet and Wirtz, 2011). On the other hand, differences in objectives by the parties can lead to the institutional investor drawing on their control rights, usually this is done at the disadvantage of the business angel (Leavitt, 2005).

In terms of the impact of networks that individual BAs maintain, Werth and Boeert (2013) identify that it is this network's size that has a significant impact on the likelihood of success, as defined by a trade sale or IPO. The direct acquaintances of a business angel play a major role in sourcing and maintaining investments as well as making them more successful, drawing on former co-investors and other direct contacts. Gregson et al. (2013) study business angel syndication in Scotland and show that syndicated investments between business angels generate larger deals and more follow-up investments. The authors identify the drawbacks that

\footnotetext{
${ }^{12}$ See also Wiltbank et al. (2009) who study the concepts of prediction and control under uncertainty, analyzing business angel investment outcomes. The authors note that some angels invest with an "affordable loss" idea, finding that the use of such a tool can be useful in decision-making under uncertain circumstances.
} 
fewer overall investments are made with less exits taking place and the generation of an equity gap in the lower market segment.

Harrison et al. (2010) examine the determinants of long distance investments ${ }^{13}$ of business angels in the UK. In their study, numerous findings provide information about the behavior of business angels as well as the evaluation methods. One finding of theirs is that large investments are more likely to be long distance investments. Second, syndicated investments are more likely to be nearby investments. The authors explain this finding with the development and maintenance of social capital relationships. Third, nearby investments tend to be more important for early stage investments. Fourth, the experience of the investor as an entrepreneur did not influence the distance of the investment. Fifth, the more investments made by a business angel, the more likely that the distance of these investments will grow. Overall, these findings indicate that investments made by more active business angels who invest larger amounts are more likely to be long distance, whilst less active business angels who invest smaller amounts are more likely to be more local.

\subsection{Conclusion and theoretical trends over time}

As in the previous section-based conclusion, we readdress the theoretical progress that BA research has made. To do so, we relate to the two general approaches of the framework presented in the introduction: (1) monitoring and interest alignment and (2) cognition, knowledge, and skill elements. More so for BA than for $\mathrm{VC}$ research, this differentiation is essential as it helps point out the heterogeneity amongst business angels, for up to date, the BA market has undergone less professional standardization than the VC industry, making BAs' cognitive features all the more relevant. Even though, same as with VC research, monitoring and interest alignment - as per Jensen and Meckling (1976) - have been studied quite thoroughly for BAs, it is found that the practice of these components is also more heterogeneous amongst BAs than amongst VCs (see, for instance, footnote 9 about the different findings of Prowse (1998) and Wong et al. (2009) in regards to board representation of BAs). There are recent shifts in the literature stating that the formation and growing sophistication of BANs has decreased these heterogeneous acts due to formalizing and streamlining investment proceedings, however, this remains to be more thoroughly investigated. Nevertheless, this

\footnotetext{
13 The authors categorize investments into three types: local (same or adjacent county), intermediate (from counties adjacent to the local counties), and long distance (investments coming from further away).
} 
progression does represent an important differentiation, as Carpentier and Suret (2015) point out that business angel and business angel network research should be clearly distinguished upon. The phenomenon of heterogeneity amongst BAs is therefore one of the primary points of discussion surrounding BA research at the moment. Moreover, it has also become more of a central topic of debate for the theoretical approaches taken to study BAs.

It is the heterogeneity amongst BAs, as well as significant cognitive differences between the typical ("average") BA and VC, that motivate the cognitive investigation into this field. In other words, the question where the heterogeneity comes from and how it influences investment behavior and outcomes has commenced to be investigated through the study of cognitive components of business angels. The phenomenon that Wirtz (2011) describes, in regards to some entrepreneur-investor relationships creating more value than others (even though agency costs are similar), shows that additional concepts are at play that go beyond the traditional monitoring, control, and interest alignment theories from the principal-agent theory. Theory more commonly used in the strategic management and general entrepreneurship literature, such as the resource based and the knowledge based views (RBV and KBV) and concepts related to decision-making style, may be instrumental in furthering our understanding of BAs' specific investment behavior and contribution. With the introduction of cognitive concepts and additional studies (see e.g. Bonnet and Wirtz, 2011), it is shown how these concepts provide BAs with benefits over other investors in certain environments and at specific investment stages.

Business angel research is thus at a crossroads. For individual BA investigations, it is likely that future research will continue to seek heterogeneity amongst BAs to further our understanding of their behavior, especially on the theoretical level using the cognitive approach. This must be distinguished, though, from BAN research. BA networks will probably continue to be investigated with a more VC-like theoretical approach, following closer along the lines of traditional agency theory due to the growing sophistication of these networks (Ibrahim (2008) also notes that BAN contracts are closer in style to those of early stage VC contracts). 


\section{Crowdfunding}

This section is dedicated to past, present, as well as future research potential. It is structured to provide an understanding of this financial mechanism in terms of past development in the market by beginning with a definition and characteristics. After, we will outline crowdfunding research development since its inception, discussing thematic hotspots. Subsequently, the three stages, as outlined in the framework introduced earlier, will be covered. Following these subsections, we provide a brief conclusion, revolving around the theoretical evolution of crowdfunding research, that seeks to tie in the reviewed literature with the theoretical framework presented in the introduction.

\subsection{Definition, relevant markets, and general characteristics}

Derived from crowdsourcing and microfinance, crowdfunding has, since its inception, diversified significantly. The term crowdfunding, coined in 2006, came as internet-based funding was a new development. Due to its internet presence, it has spread to countries all over the world. ${ }^{14}$ Furthermore, it is used to fund projects in numerous fields, such as energy, entertainment, food and beverage, e-commerce, and many more (see e.g. Hervé et al., 2016; Kuppuswamy and Bayus, 2015). It is defined as the means of an entrepreneur to connect with potential investors over the internet through platforms which present the business plan of the venture to potential investors (Griffin, 2013). Belleflamme et al. (2014) describe crowdfunding as an entrepreneur's means to collect equity from an external source represented by a large community. Bruton et al. (2015) argue that crowdfunding is one of a few new alternative means of finance, initially devised by their institutional origins, yet evolving into new forms. In other words, even though crowdfunding is filling a growing equity gap in the technology sector, it is also steadily diversifying into niches such as real estate, music, art, and many more (Felipe et al., 2017). These niches represent equity gaps that may not have explicitly existed, however, are financed by crowdfunding (see also Mollick, 2014). Bruton et al. (2015) also write that following the financial crisis, and in combination with low interest rates, the two most successful forms of crowdfunding, debt and equity, grew swiftly. Drover et al. (2017) note that crowdfunding, due to its presence in the early stages of a venture, has post-investment implications for the venture as well. These implications are, however, still an under-studied

\footnotetext{
${ }^{14}$ For France, for instance, see Bessière and Stéphany (2017) for the leading literature on crowdfunding, its operational processes, and regulations.
} 
part of crowdfunding and the reaction of venture capitalists and business angels on ventures previously funded through crowdfunding has not explicitly been investigated.

Bradford (2012) identifies five subcategories of crowdfunding based on the return provided for the capital provider: (1) donations-based, (2) reward-based, (3) lending-based, (4) prepurchase, as well as the (5) equity-based crowdfunding (see also Griffin, 2013). Model 2 and 4 are closely related and therefore the pre-purchase model is often replaced in terminology by the reward-based model. In its debt-based form, it is sometimes referred to as peer-to-peer lending. In terms of equity-based crowdfunding, multiple supplementary names have emerged: investment-based or securities-based crowdfunding or crowdinvesting.

First (1), the donation-based crowdfunding model states that an investor donates financial capital to the entrepreneur. The investor will not receive anything in return, making it a true donation. The venture may or may not be a profit seeking venture. The second (2) and third (3) models, the reward and pre-purchase models, are similar to one another and are often used interchangeably on the theoretical level. This model provides the investor a reward that is not an interest payment or a share of the profits. The pre-purchase model is exactly as the name indicates, a pre-purchase of the product that the capital provided by the investor will help create. The fourth (4) lending-based model of crowdfunding is based on loans provided by the investor to the venture. These loans can include interest payments. The fifth (5) form of crowdfunding, the equity-based form, provides investors with profit and value sharing of the venture. As this paper focuses on entrepreneurial equity finance, only this last form of crowdfunding will be reviewed. Equity based crowdfunding involves the sale of securities and is therefore highly heterogenetic across different countries due to regulatory differences (Fraser et al., 2015). Bradford (2012) notes that it is an uncommon form of crowdfunding in the US due to these regulatory issues, though Title III of the JOBS Act is changing this, as will be discussed in some more detail later. In other countries, such as Germany, law has also been altered to provide, amongst other things, better investor protection. Still, it remains a topic of discussion in Germany as well as in other countries such as France and the UK whether crowd investors are fully protected. Bruton et al. (2015) and Fraser et al. (2015) both note that regulatory issues result in more conservative growth of this particular crowdfunding sector and that it often requires strategic partnerships to allow a platform to expand into other countries. 
In formal and informal venture capital investments, there exists the capital seeker and the capital provider who are face to face (though for formal venture capital, the VC is the intermediary, as the capital originates elsewhere). In crowdfunding, there is also the platform. The form of this intermediary is unique to this financial mechanism. As this is a component essential to the workings of this financing technique, it needs to be defined. Even though not much is known about the workings, and particularly the pricing, of platforms, Belleflamme et al. (2015) provide an overview. The authors name three sources of revenue: (1) interest earned on committed capital by the crowd investor, (2) charges applicable for additional services rendered (such as payment charges), and (3) a transaction fee. Their paper also notes and provides examples of different platforms' strategies from different countries, leading to the conclusion that crowdfunding platforms are a heterogeneous field of entrepreneurial finance. Even though the authors note that crowdfunding platforms perform screening of potential ventures, the heterogeneity of these processes is also high. These differentiations amongst platforms also varies depending on the type of crowdfunding that the platform offers, as most platforms are dedicated to one of the aforementioned types.

Given that the capital provider is typically not a professional investor, compared to a business angel or venture capitalist, some more insight into this component is also valuable. In terms of the crowd itself, Hervé et al. (2016) find that most investors are men. Wallmeroth (2016) also finds that most investments come from men whilst, in terms of volume, most capital comes from strategic investors who invest less frequently but with larger amounts. By discriminating between investors, the crowd is shown to be a heterogeneous community. Furthermore, Agrawal et al. (2015) develop a concept of identifying crowd investors as friends and family. Even though crowdfunding varies significantly across its different forms as well as across different regulatory geographies, the importance of community, regardless how heterogeneous it may be, is always high. Felipe et al. (2017) note that literature remains without consensus in regards to investor characteristics and the origins of contributions, however.

\subsection{Research trends over time}

As crowdfunding, especially equity crowdfunding, is the newest form of alternative finance, its history and development is recent, yet significant. This expeditious development can be seen in in the Scopus keyword search of figure 2 with the first contribution in 2010 which swiftly grew to 64 in 2013 and to 169 in 2016 (surpassing Business Angel search results - 39 contributions - in 2016). An important factor in equity crowdfunding are the regulatory 
changes that still occur in countries offering this financial product, alterations which have the potential of changing the market. This may also be the reason why studies focus on data from single countries.

As previously defined, crowdfunding consists of multiple types, which are all included in the keyword search results. The amount of publications surrounding only the equity-based form are lower. In part, this is due to the aforementioned regulatory constraints which, in the case of Germany for instance, placed maximum investment amounts on campaigns during the initial years that it was introduced to the market (Hornuf and Schwienbacher, 2015b), thereby limiting the amount of capital that a venture could raise which, in turn, slowed the growth potential of this financial product. As this financial product was only available to accredited investors in the US (until May 2016), most currently available publications are based on European data which have only gained traction from 2014 onwards. The findings are therefore still basic and the research questions, as with venture capital research in the $1980 \mathrm{~s}$, mostly focus on the factors of success for individual campaigns. Nevertheless, much research is still evaluating the differences between the different crowdfunding types (see e.g. Bradford, 2012; Belleflamme et al., 2015; Cholakova Clarysse, 2015; Griffin, 2013). Other papers evaluate the roles and behaviors of the actors involved: Löher (2016), using interviews, is the first to thoroughly evaluate the selection procedures implemented by the crowdfunding platforms and Cholakova Clarysse (2015, using a survey) and Hervé et al. (2016, using a unique dataset provided by the crowdfunding platform) are the first to evaluate the investors in equity crowdfunding campaigns.

The range of research questions in this category of entrepreneurial finance is vast and many research gaps remain, primarily due to lack of available data. One significant aspect of this field, however, is the regulatory difference between countries (Dushnitzky et al., 2016; Hainz and Hornuf, 2016) as well as the overall heterogeneity of platforms (Belleflamme et al., 2015). Due to the low requirement of investor sophistication in crowdfunding, the regulatory bodies will likely retain strong influence on investor protection, yielding a sustainably high heterogeneity and making cross-border investments more difficult to analyze. The phenomenon found by Kaplan et al. (2007), of the use of US style contracts outside of the US, will also much less likely take place in the near future. In any case, it is apparent that crowdfunding research is still in its earliest phase of identifying and defining all of its components. 


\subsection{Pre-Investment stage: deal-flow, selection, and evaluation}

In the context of crowdfunding, deal-flow and deal sourcing as well as investment decision criteria are components which have only been researched on a very basic level. It is acknowledged that crowdfunding finances numerous industries. However, how a crowdfunding platform comes to host one venture over another has only been researched theoretically (again, when focusing on equity crowdfunding). A recent paper has emerged on the German equity crowdfunding market (Löher, 2016) and provides the only empirically dedicated paper covering this topic at this time. The determinants from the crowd as to why an individual chooses one over another campaign remains un-researched, though primitive assumptions can be made about influences on the crowd investor (see Block et al., 2016; Hornuf and Schwienbacher, 2016; Moritz et al., 2015).

\subsubsection{Identifying and accessing the capital providers}

Ley and Weaven (2011) contribute on a theoretical level by identifying 11 elements that would be required to integrate crowdfunding into entrepreneurial finance - on the level of enabling crowdfunding to provide a collective financial means to fund ventures. These factors somewhat outline the deal sourcing and target choices that a crowdfunding platform ought to have as well as traits that a venture should have to be the ideal investment choice for a crowd investor. Some of these factors provided by Ley and Weaven (2011) show interesting theoretical insight. For instance, the authors note that crowdfunding platforms should undergo deal selection with the objective of aligning the offered investment opportunities on the platform with the crowd's investment knowledge, thereby minimizing agency related costs. This objective cannot necessarily be met, however, due to the difficulties arising from the diversity of the crowd. This heterogeneity is also confirmed by Wallmeroth (2016) who identifies that, for the sample used, roughly $20 \%$ of investments generate about $80 \%$ of the funds raised, indicating a significant difference between crowd members. Hervé et al. (2016) also show that the crowd is composed of different types of people in terms of gender, age, and risk taking behavior. Women tend to invest larger amounts into safer campaigns compared to men. In conclusion to this observation, Ley and Weaven (2011) note that the model of the crowdfunding platform ought to reflect the composition of the crowd. These theoretical factors of having a heterogeneous crowd and the associated need to align the crowd with the platform also applies in Lukkarinen et al. (2016) who find that the decision criteria used by venture capitalists or angels are not entirely applicable in the field of equity crowdfunding. 
Another factor, drawing on transferable concepts from the venture capital industry, note that deal-flow stemming from external and trusted networks is essential. This is similar to the behavior described between business angels and venture capitalists in that deals suggested to business angels by venture capitalists are more likely to make it through the business angels' investment decision process (Croce et al., 2016b). Furthermore, Ley and Weaven (2011) note that it should not be essential to communicate confidential information to the crowd. This goes hand in hand with another posited factor, that a venture should not have characteristics that require much due diligence. These two items indicate that a venture should not be overly complex in nature, particularly with its business model. Even though their first theoretical observation notes that crowd investors should be knowledgeable and experienced investors, these last two items are a practical reflection of the low level of sophistication of many crowds in the industry. This level of sophistication, however, is still being debated throughout the literature (see Ahlers et al., 2015; Brown et al, 2015; Vismara, 2016). These discussions show that the crowd is a heterogeneous community in which the larger-amount investors are, arguably, more sophisticated investors than others and play an important role as a subpopulation. To provide a somewhat conclusive argument, it is shown that crowd investors are susceptible to signaling and are influenced by comments left by other investors as well as news updates posted by the venture during the campaign and third party communication (Block et al., 2016; Hornuf and Schwienbacher, 2016; Moritz et al., 2015). These findings suggest that crowd investors do not only rely on the information provided to them on the platform to make their decisions. These investors also depend on each other, which is also evident from Wallmeroth (2016) who notes that crowd investors use forums to discuss investment opportunities.

\subsubsection{The pre-investment stage for platforms}

Löher (2016) conducts a qualitative study by interviewing platform operators, funded ventures, as well as experts in equity crowdfunding. The author finds that the selection process is structured, requires pro-active searches by the platform, and relies heavily on the network of those involved. The author distinguishes between four stages before a venture commences its campaign: (1) sourcing of deals, (2) screening and evaluation, (3) structuring the deal, and (4) preparing the campaign. It must be noted that this fourth step is exclusive to crowdfunding and is not present in business angel nor formal venture capital investing. Especially in stage (1), the sourcing stage, the platform heavily relies on its network. The author notes that only one 
of the interviewed ventures successfully campaigned through a direct application on the platform. At this stage, the platform also follows the argument brought forth by Ley and Weaven's (2011) to align the platform with its crowd. In stage (2), the screening process filters the application through early obstacles, such as the required legal form of the venture as a legal entity. The evaluation portion of this stage is more thorough, looking at the pitch deck of the venture, existing investors, personal meetings to assert the management team, as well as conducting investigative checks. The third (3) stage conducts the structuring of the deal which includes the valuation, the minimum and maximum funding amounts, as well as the platform's fees. The valuation methods used vary significantly, from multiples to VC methods, or auction methods and more. The final stage (4) allows the venture to create a profile that informs and attracts potential investors. To get attention from potential crowds, platforms utilize multiple channels of communication, including press releases, social media, and newsletters. The use of these communication channels is, again, unique to the crowdfunding industry. The study of these unique traits is an area in which empirical studies have much potential to investigate. As this study was conducted using German crowdfunding platforms, it remains to be seen to what extent it can be extrapolated to other countries, leaving a large research gap in this field as well.

\subsubsection{The pre-investment stage for entrepreneurs}

In terms of selection analysis by the entrepreneur, Belleflamme et al. (2014) study the decision of an entrepreneur choosing between pre-ordering or equity as the type of crowdfunding to be used. Their paper notes that entrepreneurs favor reward based crowdfunding if the required capital is small in comparison to the overall size of the market. If this is not the case, entrepreneurs favor the equity based model of crowdfunding. The authors further highlight the strategic difference between these two forms of crowdfunding: the pre-order model allows entrepreneurs to get a sense for pricing of the product. As crowd investors who use the reward based model are typically interested in the product and are likely to become regular consumers, they allow the entrepreneur to discover the price limits of the product.

\subsection{Investment stage: ownership structure and contracting}

The degree to which crowdfunding has been studied suggests that the ownership structure is primarily a concern for the equity based version. However, not much research has been conducted in this field in terms of ownership structure and contracting. As for non-equity crowdfunding, ownership structure and contracting have not been studied significantly either. Due to the equity-based literature being reviewed by this article, non-equity crowdfunding will 
not be reviewed, however, it does represent a knowledge gap. One additional gap is the aspect of equity investments made by VCs into ventures after they are funded by non-equity crowdfunding campaigns. For equity crowdfunding, however, one of a few papers that discuss deal structuring to some extent is Signori and Vismara (2016) who find that the average equity offered in equity crowdfunding in their sample is $14.8 \%$.

\subsubsection{Common securities}

Crowdfunding, in its numerous forms, has unique contractual structures depending on its type as well as the platforms location (see Hornuf and Schwienbacher, 2015a, 2015b; Klöhn and Hornuf, 2012; Klöhn et al., 2015, 2016; Schwienbacher and Larralde, 2010; Wroldsen, 2016). In the US, Wroldsen (2016) identifies six common types of securities: common stock, preferred stock, interest-bearing loans, revenue-sharing arrangements, convertible debt, and future equity. The author note that crowdfunding contracts are simplified versions of contracts utilized by VCs and that, due to this simplicity, the crowd is better protected by closely following social media and listening to statements coming from other crowd members than by the protection coming from the contracts. This behavior of the crowd is also found by Wallmeroth (2016) who finds that crowds not only use the platform's comments section to inquire and discuss ventures, but are also active on third party forums, creating threads of discussions on each venture related to campaign starts, exits, and frequently the well-being and status of active investments.

Wroldsen (2016) finds that in the US, common stock is the most frequently used security. In the cases that voting common stock is issued to the crowd, it typically represents either a minority, or higher class voting stock was issued to management, rendering the potential votes and influence of the crowd unlikely to affect decisions of the venture. Furthermore, antidilution rights, though offered by one venture, are also explicitly denied by another. The contracts in crowdfunding are therefore still heterogeneous in the US. For preferred stock, the second most frequent security, the contracts vary as well.

\subsubsection{Regulatory changes}

In terms of contractual knowledge of the crowdfunding industry, much research potential still exists, especially in the growing market of equity crowdfunding which only commenced in the 
US in $2016^{15}$. However, even in more mature markets, such as France, Germany, and the UK, contracts are still changing and being influenced by regulatory bodies, trying to enhance investor protection. Dushnitzky et al. (2016) also note that in Europe, country-dependent regulations draw strict borders between these nations, citing economic, cultural, and legal aspects as influential variables (see also European Crowdfunding Network, 2014). In the case of Germany, regulation passed in 2015 on equity crowdfunding still leaves some room for investor protection as pointed out by Klöhn et al. (2015).

\subsection{Post-investment stage: behavior, growth, and success/failure}

The post-investment stage of equity crowdfunding has not yet been studied thoroughly and is only in its initial stages. Even though crowdfunding needs to be distinguished depending on its type, not many empirical investigations have been performed on any type in terms of returns. The measure of success in crowdfunding which has mostly been retained is the success of individual campaigns. This is partly due to the difficulty of obtaining data whilst there is also a shortage of observations, at least in the case of equity crowdfunding. Hornuf and Schwienbacher $(2014,2016)$ note that there is a lack of data available and that the data that is available usually comprises small sample sizes. Furthermore, the majority of equity crowdfunding investments in the German equity crowdfunding market are still active and do not lend themselves to the analysis of divestments (Hornuf and Schmitt, 2016b; Wallmeroth, 2016). Signori and Vismara (2016) are perhaps the only researchers analyzing the divestments of equity crowdfunding campaigns on an empirical level. Hornuf and Schmitt (2016b), whilst also discussing success and failure in equity crowdfunding, do so on a descriptive level of information.

Though the studies on the crowd also have implications for the pre-investment stage, their postinvestment stage implications are also notable and need to be addressed here due to the, somewhat, unclear cut between the two stages in crowdfunding. In other words, the first investor of the campaign, who has committed his capital (unless, as with most campaigns, the minimum investment amount is not raised in which case the capital is returned), could arguably already be in the post-investment stage whilst prospective investors are still in the pre-

\footnotetext{
${ }^{15}$ In the US, equity crowdfunding was nigh impossible due to regulatory constraints. However, the SEC released new legislature at the end of 2015 (Title III of the JOBS Act), allowing equity crowdfunding to take place (with a half a year delay). Thus, on May $16^{\text {th }}, 2016$, equity crowdfunding was enabled for all types of investors and is now offered to ventures as a source of capital. For more information see Klöhn et al. (2015) and Wroldsen (2016).
} 
investment stage. This phenomenon, of one investor being in the post-investment stage, can have influence on those investors who are still in the pre-investment stage.

Vismara (2016a) shows that signaling amongst these individuals is also highly influential. The author finds that the initial days of a campaign are essential in determining the successful outcome of a campaign. Furthermore, public profile investors, those individuals who link their investment profile to their social media, are highly influential in terms of attracting other investors to a campaign during its initial days. The importance of such individuals in reducing uncertainty and perceived risk can also be confirmed by the findings of Ahlers et al. (2015) who show that equity crowd investors rank a high importance on the level of uncertainty. The importance of the entrepreneur's social connections is also shown to be significantly influential in decreasing information asymmetries between the entrepreneur and investors in the equity crowdfunding market (Vismara, 2016b). These findings are confirmed for the German equity crowdfunding market as well, where Hornuf and Schwienbacher (2016) find an L-shaped dynamic. This dynamic was first researched by Kuppuswamy and Bayus (2015) in the context of reward based crowdfunding. In this context, the authors find a U-shaped dynamic, meaning that contributions to a campaign are received primarily during the first and last week. Hornuf and Schwienbacher's (2016) research reflects the first-come first-served model of equity crowdfunding. Therefore, this dynamic, the authors argue, should reflect the behavior of securities allocation mechanisms which posits an L-shaped dynamic - that contributions are received mostly at the beginning of the campaign. This behavior is then empirically identified by showing that most investments occur during the initial stage of the campaign - though there is also a slight increase in investments during the final three days, the authors conclude that an L-shape dynamic is at play.

Signori and Vismara (2016) research this stage of investments for equity crowdfunding in terms of financial returns. Their data shows that $10 \%$ of successfully crowd financed campaigns failed whilst 30\% sought additional financing or were sold. This means, however, that returns for investments which have neither gone bankrupt nor received additional financing or were sold, are unknown. The $30 \%$ of ventures that did receive subsequent financing or were sold yield an expected rate of return of $8.8 \%$. Given the entry of the US into the equity crowdfunding market in the first half of 2016, more data will hopefully be available for further research whilst the ongoing campaigns of the European market will provide more insight into the outcomes of such investments. However, the numerically limited number of equity 
crowdfunded ventures that have indeed been divested often do not publicize the realized returns. For the German market, Hornuf and Schmitt (2016b) note that the ventures that offered an exit opportunity to its investors did so due to the interest of business angels and venture capitalists who wanted to invest into the start-up. The authors also note that for the German, as well as the UK market, several ventures received external capital from either venture capitalists or business angels prior, during, or after the crowdfunding campaign. Such influence on equity crowdfunding remains under-researched and the role of such certification as well.

Determinants for success of an individual campaign have been studied for some years now. Some of these studies focus on the initial days of a campaign as an indicator for success (see Colombo et al., 2015; Hornuf and Schwienbacher, 2016). Though some of this research covers non-equity crowdfunding, important aspects are discovered or named which are relatable to the equity based version and therefore represent research gaps in this field. Colombo et al. (2015) look at the internal social capital and its effects on the number of investments and the amount of investment generated during the initial days of a campaign launch. Internal social capital is the extent of social contacts within a collective, or community. It is the internal social capital that contributes during the initial days of a campaign and it is found that both the number and amount of early contributions are strongly associated with the success of a campaign. The economic impact of the number of early backers is so strong, that a one standard deviation (1.5) increases the probability of success from $9 \%$ to $17 \%$. For capital contributed, the economic impact is even stronger, augmenting it from $9 \%$ to nearly $22 \%$ (where one standard deviation is 0.07$)$. In terms of internal social capital, it is found that it has a stronger impact on the number of early contributors than the amount of early contributions. Mollick (2014) also studies the determinants of success of crowdfunding campaigns on a US crowdfunding platform, focusing on the reward-based as well as the donations-based model. The author's findings that influence the likelihood of success include personal networks and social capital, project quality, and geography. The importance of signaling in crowdfunding is reflected by the attention that funders pay to the preparedness and quality of the idea. The projects which succeed are shown to achieve only small margins whereas if they fail, the margins are more significant. In regards to the reward based model, the author finds that most projects experience a delay in delivering which is even more so the case for campaigns that are overfunded. The phenomenon of overfunding and its effects, also prevalent in equity crowdfunding, also remains open for investigation. 


\subsection{Conclusion and theoretical trends over time}

Crowdfunding is still a dynamic component of entrepreneurial finance. Many of its behavioral traits, including theoretical understanding in relation to the theoretical framework presented in this article's introduction, remain to be explored. In part, this is due to the "mystery" surrounding the actors involved. For VCs and BAs, the actors' identity is clear: whether it is the investor, capital provider, or capital receiver. For crowdfunding, however, the capital provider is still an unknown component and thus not entirely understood: specifically, the crowd. ${ }^{16}$ This has significant impact on the theoretical framework components used by this article, also because what is known about the crowd is that it is highly heterogeneous (Hervé et al., 2016).

Though components of monitoring, control, and interest alignment are being studied and are observable between the crowdfunding platforms and the entrepreneur (as shown by Löher, 2016), this component remains to be explored in other countries and jurisdictions. Further, it still needs to be investigated when factoring in the crowd as such (beyond the platform and its managers). In other words, how does the crowd monitor and control, align interest, and how are cognitive and knowledge components integrated into the investment procedure? Crowdfunding is therefore a highly complex field of study as, in all likelihood, research will need to distinguish between investigations involving the crowd or discarding it. Ventures and crowdfunding platforms, once better understood by scholars and more established in the market, will likely be studied primarily using traditional agency theory components, namely monitoring, controlling, and interest alignment. Yet, when including the crowd, it is probable that cognitive and knowledge components will be required to authentically understand its decision making and investment process.

It is therefore interesting to follow crowdfunding research and to see to what extent the crowd will be integrated into research and its theories, or to which extent it will be put on the sidelines (as most VC literature also does not assess the reasons why an endowment or pension fund may give their capital to one $\mathrm{VC}$ fund rather than another). Here, the different types of crowdfunding will also play different roles, as the crowd has drawn most interest by scholars in its equity-based form.

\footnotetext{
${ }^{16}$ This does not mean that the other two mechanisms are understood entirely as research is still determining what sort of start-up is more likely to crowd fund than another. Furthermore, the platforms are also found to be highly heterogeneous (see e.g. Belleflamme et al., 2015).
} 


\section{Institutional seed investors, business angels, and the crowd acting together}

This section is dedicated to literature that revolves around a combinatory study of venture capital, business angel, and crowdfunding. Herein, we assess the past and present as well as future potential of this area of research. Sources focus on general behavioral aspects of such investors when investing together, making a structural differentiation between investment stage less practical. As in earlier sections, however, we will place emphasis on thematic hotspots and highlight aspects relevant to the three stages when relevant.

The literature puts increasing focus on syndication and co-investments for investments made by the same type of financial mechanism (intra-group) and its counterparts (inter-group). Therefore, research is making progress from analyzing business angels and venture capitalists investing in their respective groups or networks (see e.g. Bonini et al., 2016; Brander et al, 2002; Bygrave, 1987, 1988; Capizzi et al., 2016; Casamatta and Haritchabalet, 2007; Chemmanur and Tian, 2011; Goldfarb et al., 2014; Ibrahim, 2008; Mason and Harrison, 2002) to investing alongside one another (see e.g. Bonnet and Wirtz, 2012; Chahine et al., 2007; Dutta and Folta, 2016; Elitzur and Gavious, 2003; Goldfarb et al., 2014; Hellman and Thiele, 2015; Mason and Harrison, 2002; Mason et al., 2016; Morrissette, 2007). The more recent literature also identifies business angels as providers of capital for crowdfunding (Brown et al., 2015; Hornuf and Schmitt, 2016a; Mason and Botelho, 2014). These financial mechanisms, however, have different objectives and play different roles as mentioned earlier. These differences can lead to conflict and tension. Although, they also have the potential to generate additional value (see Bonnet and Wirtz, 2011). It is with assessing these differences and their effects on ventures that the literature is investigating this aspect of entrepreneurial finance.

\subsection{Business angels and formal venture capitalists}

Drawing on some of the literature discussed and knowledge provided prior to this section, Morrissette (2007) presents a succinct overview of the differences between formal and informal venture capitalists (see table 3). De Clercq et al. (2006) also provide general differences between these two financial techniques throughout the investment stages, drawing on existing literature. Bonnet and Wirtz (2011) also highlight the differences between formal VCs and BAs, especially in terms of (1) specific economic incentives and (2) typical cognitive differences between the two investor categories, due to particular mindsets, specific experience and skills, etc. Referring to different theoretical approaches to venture governance, namely agency theory and resource- and knowledge-based theory, the authors go on to study the 
implications of these differences for the interaction between VCs, BAs and the entrepreneurs. They show that the typical BA's mindset is supposed to be located between professional VCs and entrepreneurs, putting them in a privileged position to bridge possible cognitive differences, by translating entrepreneurs' original ideas into the more formal financial language of business plans. This, in turn, may help attract large amounts of funding from VCs, helping ventures with especially high growth potential to dispose of the necessary funds to achieve such growth on the basis of simultaneous co-investment.

Table 3 Differences between business angels and venture capitalists

Mason et al. (2016) note that due to their differences, it is not easy for business angels to coinvest with institutional seed investors because of conflicting objectives. Venture capitalists seek to determine the right time to exit, which can pose a problem with co-investors (also see Morrissette, 2007, specifically the findings on exit strategies and return expectations). These notable issues could explain the rise in BANs as well as the apparent increase in business angel activity in crowdfunding where a business angel can raise additional required capital for larger deals. However, given the inconsistent findings on co-investments between formal and informal investors, in terms of circumstances in which they are beneficial and in which they can cause value degenerating conflicts, extensive gaps still exist. This is particularly true when observing that these studies are often bound by geographic setting and are, most likely, affected by local cultural practices or country related regulatory effects.

The general difference between the two is also analyzed by van Osnabrugge (2000) in a study based on interviews and questionnaires. The author discusses multiple aspects of the preinvestment, investment, and the post-investment stages, finding that venture capitalists have greater deal-flow and are more selective in their screening procedures. Though not conclusive, it is highly probable that VCs also perform more due diligence in the pre-investment stage. The behavior is further assessed through contractual differences, where the author notes that VCs probably have more contractual control over their investments. Though VCs may have this superiority contractually, BAs are found to perform more active monitoring post-investment, though the author notes that this finding is not entirely conclusive. VCs, however, are more concerned with the exit of the investment than BAs are. These findings are, provided the earlier definitions and roles, not surprising. However, given the tentative nature of some of these 
findings, research still needs to elaborate on solidifying our understanding of these differences when these financial mechanisms interact on the same investment.

Though some studies focus on the differences between formal and informal venture capitalists, Harrison and Mason (2000) assess angel and venture capital investments in the UK through survey analysis and discover that the link between these two is higher than anticipated. The authors' findings include the link between the financial techniques for deal referrals as well as, though less frequent, sequential and simultaneous co-investing. These forms of complementarity, as the authors describe it, are split by venture capitalists referring deals to business angels (half co-invest with business angels or provide follow-up financing to ventures financed by business angels). The most frequently observed form of complementarity of business angels is to co-invest (simultaneously or sequentially). The authors additionally note that, though the two have different objectives and roles, both the sequential as well as the simultaneous co-investments experience positive relationships, with a positive effect also for the venture.

Goldfarb et al. (2014) conduct an empirical study on the investment structure and outcomes when business angels or venture capitalists invest into a venture separately as well as when they co-invest. By looking at the investment and post-investment stages, the authors find that co-investments for large deals between business angels and institutional seed investors lower the success rate. Nevertheless, co-investments between the two are frequent and the two actors often invest using the same preferred stock and are both provided control rights. The authors note, though, that it is high-end angels that negotiate similar contractual terms as VCs do. The presence of a business angel in a deal does result in weaker cash flow and control rights.

\subsection{Theoretical understanding of BA and VC co-investments}

Another recent paper, by Hellman and Thiele (2015), applies a theoretical framework to investigate the interaction between angel investors and venture capitalists. The authors note that these two financial mechanisms are both friends and foes when financing ventures. Their relationships are based on the mutual necessity of their financial capital for financing rounds. However, this relationship can turn unfriendly over time due to the diminishing necessity of an angel's financial capital for subsequent funding rounds. Another important aspect identified by the authors is the role of legal protection and its developments during the investment stages. When BAs have lower protection, valuations also decrease. The authors note that this is the 
result of weaker bargaining power at the VC stage of financing. The authors identify this as a perception of a "sunk" investment where subsequent financing rounds are determined by the institutional investor, not the BA. This is the case when the BA is not able to, through individual means, raise the financial capital to provide subsequent funding and is therefore dependent on the VC's capital. This situation is referred to as a "burned angels" (see also Leavitt, 2005 who describes the term as angels who once held significant equity stakes in firms that were then diluted and ultimately exited by the $\mathrm{VC}$ for much higher returns than the wronged angel received at a prior payout date).

Elitzur and Gavious (2003) also use a theoretical approach to assess the dynamics between the two financial techniques (alternatively three, as the authors include the entrepreneur). The authors investigate the moral hazard that develops when both business angels and venture capitalists co-invest, making the entrepreneur and the venture capitalists "free riders" when taking a business angel's money. This is due to the entrepreneur and the $\mathrm{VC}$ minimizing their efforts to the disadvantage of the angel investor. Though this behavior can be mitigated through governance and financial control mechanisms, it cannot be entirely removed. The authors also indicate that the signaling effect of an entrepreneur approaching an angel, or generating some form of a cost in contacting an angel, is a positive signal. The findings indicate that research gaps remain at each stage of the investment process when investigating the interaction of formal and informal investors.

In another theoretical paper, Schwienbacher (2009) analyzes the consequences of an entrepreneur seeking capital from business angels or venture capitalists. The author finds that business angels are more value adding in early phases of the venture due to their resources and the associated incentives (see also Goldfarb et al., 2014 who find that BAs investing individually invest into younger and smaller firms). This added value augments the venture's valuation, and in combination with the venture capitalists' more equipped capital resources, positions the $\mathrm{VC}$ as a follow-on capital provider at a later stage. The author summarizes that entrepreneurs who are less fond and in search of control-oriented investors ought to choose business angel financing whilst a managerial approach should seek institutional seed capital. The compromise would be to use a co-investment of the two. Theoretical assessments, as concluded by the author, also give way to new questions, such as the alignment of interests between the capital providers and the capital seekers in early stage investments and how these interests vary when more than one type of investor seeks to invest. 


\subsection{The cognitive element of co-investments}

Most of the remaining literature that falls into this category of combinatory studies deals with the impact of differences on behavior and interaction using surveys, interview, or questionnaires. Bonnet and Wirtz (2012) enhance their earlier paper (see Bonnet and Wirtz, 2011) by using a case study design to assess the interaction of business angels and venture capitalists when co-investing. The case study shows that cognitive issues (gaps in knowledge between the involved) are particularly heightened during the pre-investment stage between the venture and the prospect capital provider with the business angel taking the lead during this stage of the investment. The cognitive issues shift to the traditional agency problems which arise during later stages (investment stage) and are predominantly venture capital led. BAs can therefore act as translators of the value creation potential of the venture in earlier stages and play a significant role in the early stage of the investment process when co-investing with VCs. Due to their specific cognitive features, the BAs' translation of the potential of value creation into financial language is more readily understood by VCs. The study of the interaction between these two is developed further by Bonnet et al. (2013) who survey business angel investments in France and assess the impact of such investments (as well as the co-investments with venture capitalists) on the growth of the financed ventures, finding that particularly strong growth rates are found in ventures that are simultaneously co-financed by the two.

\subsection{Co-investment studies of specific investment stages}

Literature that is dedicated to specific investment stages includes Chahine et al. (2007), Dutta and Folta (2016), and Drover et al. (2017). These papers focus on the pre- and/or postinvestment stages. Chahine et al. (2007) compare the IPO performance of BA and VC funded ventures in France and the UK. Here, differences exist between the two countries as indicated by the empirics. UK IPOs are found to have lower underpricing than French IPOs. Further, UK IPOs exhibit a higher stake of BAs than French IPOs. French entrepreneurs appear to have higher appreciation for VC involvement than UK entrepreneurs (as indicated by the difference in ownership: $11.8 \%$ in France compared to $4.3 \%$ in the UK). Another significant difference between the two markets is the handling of ownership by the investors during the IPO. In the UK, BAs and VCs retain their ownership whilst in France, VCs use IPOs to divest. Further papers examine yet other effects on the post-investment stage. Dutta and Folta (2016) note that empirically investigating business angel investments remains challenging due to the difficulty of observing such investments resulting from their private nature. The authors investigate the 
impact of angel networks and VC investments on ventures in terms of added value, trying to identify differences between the two. The authors find that angel network and VC investments are equally contributory towards innovation (measured by increase in patent rates). VCs are found to have higher impact with their value adding attributes, though. This presents itself through an increase, not in the rate of innovation, but in the impact of innovation as measured by a larger citation of patents under VC-backed ventures.

Drover et al. (2017) focuses more on the pre-investment stage. The authors note that investments which are funded by experienced business angels and angels who are members of known angel networks have a higher likelihood of being selected by VCs for entering a formal due diligence process. The same is found for reputable crowdfunding platforms with a track record of financing high quality ventures. Bruton et al. (2009) note that a firm's investors can also be a certification of quality and value (see also Daily et al., 2003). Certification in the early stages of finance remain under-studied, however, and provides another extensive research gap.

\subsection{Business angels and crowdfunding}

Business angels, as Berger and Udell (1998) point out, differentiate themselves from institutional seed investors, as well as from crowdfunding, in one paramount way: there is no intermediary. A business angel makes a direct investment into the venture. When a business angel invests through crowdfunding participation, this direct investment approach is sacrificed. However, such an investment enables the business angel to engage with the venture and begin building an investor-based relationship which may yield future and larger investments by the business angel on a more direct investment route. In terms of the interconnectedness of business angels and crowdfunding, little research has been done and the heterogeneity of regulations across countries also has significant implications on any findings (Hornuf and Schwienbacher, 2014, 2015a, 2015b). Bruton et al. (2015) note that further research in this context is still required, citing the Enterprise Research Centre (2014) which found that nearly $44 \%$ of surveyed business angels had invested through crowdfunding. Wright et al. (2015) also find that business angels increasingly co-invest in crowdfunding. Mason and Botelho (2014) find this as well, however, at a lower level (22\%). More conclusive studies on the behavior and intentions of BAs in crowdfunding remain to be seen and are, perhaps, one of the most sought after topics at this stage. However, the data availability and collection provides the most difficulties. 


\subsection{Conclusion and theoretical trends over time}

The literature involving at least two of the aforementioned investor-types shows that significant differences exist among them, even if they are known and found to frequently cooperate, interact, and thrive off each other. The literature also provides insight into the complexities of these exchanges and the previous sections have highlighted some of the differences of these financial mechanisms not only on a behavioral level, but also on a theoretical level when it comes to the research surrounding them.

Therefore, at this point, it is interesting to tie venture capital, business angel, and crowdfunding research together, using the theoretical framework depicted in figure 1 in order to understand their interconnection on a theoretical level. Where VC research has historically primarily evolved through the application of agency conflict, it has, nevertheless, come to the attention of scholars that VCs can also be investigated using cognitive diversity (Bonnet and Wirtz, 2012). Whilst this study compares the cognitive diversity of VCs and BAs, it can be observed that both VCs and BAs exhibit specific cognitive functions throughout each investment stage. The same can be said about the components of agency theory, that is to say that agency conflict may take on specific forms depending on different stages of the investment process and on the specific actors that co-invest (BAs, VCs, the crowd). VCs for example exhibit heterogeneity as discussed by Ooghe et al. (1991) and Manigart et al. (2006), regarding US and EU venture capital funds. Generally, VCs have more homogeneous agency-driven practices than BAs, but they have been shown to feature cognitive specificities, for instance, due to geographic differences. This compares to BAs who, generally, exhibit more heterogeneous agency-driven practices. Therefore, when assessing these investor types together, it is found that agency and cognitive components play different roles for each respective investor-type at different stages of the investment process and in different geographies.

At this time, it is still difficult to ascertain how crowdfunding will be integrated into studies involving either VC or BA components. Most of the literature has picked up on business angels investing in crowdfunding campaigns, however, VCs have also placed investments into such campaigns. 


\section{Conclusion}

This paper provides an overview of a vast body of literature, presenting the contemporary state of research and succinctly identifying subcategories in the fields of institutional seed financing, angel financing, and crowdfunding. By reviewing this literature, we present major research trends as well as research gaps using a theoretical framework. We also present the evolution of the entrepreneurial finance market to demonstrate the growing complexities of the market and its participants (see figure 4). To conclude, we provide a summarizing overview of the most prevalent literature gaps for each market participant.

Figure 4 The market for entrepreneurial finance and its evolution over time (as reflected in research)

Figure 4 gives a simplistic view of the growing complexities of the entrepreneurial finance market. This growth is also found in the research gaps. Most prevalently, these intricacies are the result of the interactions between financial mechanisms. This is confirmed by researchers having only begun to study business angel networks in recent years - in other words when business angels co-invest amongst each other, not even when investing with other financial mechanisms. This gives food for thought as to the potential amount of research still underway and the knowledge yet to be gained - particularly as co-investments amongst BAs was already known to exist in the early 1980s (Wetzel, 1983). This is particularly true in regards to coinvestments and cooperation between crowdfunding and business angels or institutional investors, thus representing perhaps the most significant research gap at this point in time. On the other hand, the study of these individual actors remains far from complete as well.

Institutional investors active in the seed stage of entrepreneurial finance will likely see an additional shift towards emerging markets as well as more in-depth research on co-investments with their peers and other actors in the market. Cumming and Zhang (2016) explain this and review VC literature for emerging markets, showing a significant increase in recent years. Furthermore, two other focal topics exist that can do with additional investigations. For one, the exact expectations that VCs have of their investments remain under-researched. Second, even though the entrepreneurial literature finds that co-investments between these capital providers work in theory and also exist and function in reality, little research has covered them specifically in cross-border settings. 
In terms of business angels, the largest research gaps revolve around the understanding of BANs as well as BA co-investments. Though some research has been conducted on the differences between informal and formal venture capitalists, literature starts to pick up on the more prevalent differences amongst BAs themselves. Even though a trend is developing on informal venture capital differences, the publication potential concerning BA and VC coinvestments is still filled with many avenues of research that remain unexplored. Not only the pre-investment, investment, and post-investment stages are still under-researched, but also the different approaches from an agency and cognitive approach. Furthermore, the role of BAs in crowdfunding is also still a research gap that needs further addressing along with detailed datasets that allow for clear-cut differentiations between investors.

For equity crowdfunding, countless aspects remain under-researched or not researched at all. Specifically, it is the regulatory settings and differences between countries that will make it interesting to see a global competition between platforms and their regulatory constraints, contracting scenarios, as well as the investment opportunities which they provide. Papers all focus on a single platform in a single country, perhaps offering descriptive information on that country's equity crowdfunding scene. However, no paper has yet addressed continental Europe, the US, or a global approach to equity crowdfunding. Furthermore, equity crowdfunding will likely require additional research and understanding of the interaction between this type of crowdfunding and BAs as well as VCs. This form of alternative finance is also drawing the attention of wealth management firms and banks, yet these developments may be acute due to historically low interest rates.

The present work contributes to research in the fast developing field of entrepreneurial finance by giving structure to a vast and ever-growing literature. Such structure is achieved through the overarching framework proposed in the introduction. The relevance of this framework, which can be applied to all players of the evolving market for entrepreneurial finance at different stages has been demonstrated through the literature review. Among other things, it shows that entrepreneurial finance features a specificity when compared to more traditional corporate finance, which is the relative importance of the cognitive influence of the players in the field, in addition to the widely studied impact of potential agency conflicts. The prevalence of such cognitive issues appears, however, to be dependent on investment stage which is an important avenue for more systematic future research. 


\section{References}

Aernoudt, R. 1999. Business angels: Should they fly on their own wings? Venture Capital: An International Journal of Entrepreneurial Finance 1, no. 2: 187-195.

Agrawal, A., Catalini, C., Goldfarb, A., 2014. Some simple economics of crowdfunding. Innovation Policy and the Economy 14, 63-97.

Agrawal, A., Catalini, C., Goldfarb, A. 2015. Crowdfunding: Geography, Social Networks, and the Timing of Investment Decisions. Journal of Economics and Management Strategy 24, no. 2: 253-274.

Ahlers, G. K., Cumming, D., Günther, C., Schweizer, D. 2015. Signaling in Equity Crowdfunding. Entrepreneurship Theory and Practice 39, no. 4: 955-980.

Amatucci, F. M., Sohl, J. E. 2004. Women entrepreneurs securing business angel financing: tales from the field. Venture Capital: An International Journal of Entrepreneurial Finance 6, no. 2/3: 181-196.

Amit, R., Brander, J., Zott, C. 1998. Why do venture capital firms exist? Theory and Canadian evidence. Journal of Business Venturing 13, 441-466.

Audretsch, D. B., Lehmann, E. E. 2004. Financing High-Tech Growth: The Role of Banks and Venture Capitalists. Schmalenbach Business Review 56, no. 4: 340-357.

Balachandra, L., Sapienza, H., Kim, D. 2014. How critical cues influence angels' investment preferences. Frontiers of Entrepreneurship Research 34, no. 1: 1-16.

Balboa, M., Martí, J. 2001. Determinants of private equity fundraising in Western Europe. Available at: https://ssrn.com/abstract $=269789$.

Barry, C. B. 1994. New directions in research on venture capital finance. Financial Management 23, no. 3: 3-15.

Barry, C. B., Muscarella, C. J., Peavy, J. W., Vetsuypens, M. R. 1990. The role of venture capital in the creation of public companies: Evidence from the going-public process. Journal of Financial Economics 27, no. 2: 447-471.

Belleflamme, P., Lambert, T., Schwienbacher, A. 2014. Crowdfunding: Tapping the right crowd. Journal of Business Venturing 29, no. 5: 585-609.

Belleflamme, P., Omrani, N., Peitz, M. 2015. The economics of crowdfunding platforms. Information Economics and Policy 33: 11-28.

Bengtsson, O. 2011. Covenants in Venture Capital Contracts. Management Science 57, no. 11: 1926-1943.

Bengtsson, O. 2013. Relational venture capital financing of serial founders. Journal of Financial Intermediation 22, no. 3: 308-334.

Bengtsson, O., Hsu, D. 2010. How do venture capital partners match with startup founders? Available at: https://ssrn.com/abstract $=1568131$.

Berger, A. N., Udell, G. F. 1998. The Economics of Small Business Finance: The Roles of Private Equity and Debt Markets in the Financial Growth Cycle. Journal of Banking and Finance 22, no. 6, 613-673.

Bessière, V., Stéphany, É. 2017. Le crowdfunding: Fondements et pratiques. De Boeck, $2^{\text {nd }}$ edition.

Bhide, A. 1994. The origin and evolution of new businesses. Oxford: Oxford University Press.

Black, B., Gilson, R. J. 1998. Venture capital and the structure of capital markets: banks versus stock markets. Journal of Financial Economics 47: 243-277.

Block, J., Hornuf, L., Moritz, A. 2016. Which Updates During an Equity Crowdfunding Campaign Increase Crowd Participation? Available at: http://ssrn.com/abstract=2781715.

Bock, C., Schmidt, M. 2014. The sooner, the better? Venture Capital decisions in IPOs. Frontiers of Entrepreneurship Research 34, no. 2: 16-31. 
Bonini, S., Alkan, S., Salvi, A. 2012. The Effects of Venture Capitalists on the Governance of Firms. Corporate Governance: An International Review 20, no. 1: 21-45.

Bonini, S., Capizzi, V., Valletta, M., Zocchi, P. 2016. Groups, networks and business angels' investment process. Available at:

https://www.google.com/url?sa=t\&rct=j\&q=\&esrc=s\&source=web\&cd=2\&cad=rja\&u act $=8 \& v e d=0$ ahUKEwii5tKaidjPAhWFvBQKHS0QAVsQFgglMAE\&url=http $\% 3 \mathrm{~A} \%$ $2 \mathrm{~F} \% 2 \mathrm{Fwww} . \mathrm{em}-$ lyon.com\%2Fminisiteen $\% 2 \mathrm{Fcontent} \% 2 \mathrm{Fdownload} \% 2 \mathrm{~F} 169692 \% 2 \mathrm{~F} 6659851 \% 2 \mathrm{Ffile}$ $\% 2$ FBonini $\% 2 \mathrm{C} \% 2520$ Capizzi $\% 2 \mathrm{C} \% 2520$ Valetta\%2C\%2520Zocchi\%2520$\% 2520$ Groups $\% 2$ C $\% 2520$ networks\%2520and $\% 252$ business $\% 2520$ angels\%25E2\%2 580\%2599\%2520investment\%2520process.pdf\&usg=AFQjCNEsVUkeYFHztI9d71g biIlpRNzPRQ.

Bonnet, C., Wirtz, P. 2011. Investor Type, Cognitive Governance and Performance in Young Entrepreneurial Ventures: A Conceptual Framework. Advances in Behavioral Finance and Economics: The Journal of the Academy of Behavioral 1, no. 1: 42-62.

Bonnet, C., Wirtz, P. 2012. Raising capital for rapid growth in young technology ventures: when business angels and venture capitalists coinvest. Venture Capital: An International Journal of Entrepreneurial Finance 14, no. 2: 91-110.

Bonnet, C., Wirtz, P., Haon, C. 2013. Liftoff: when strong growth is predicted by angels and fueled by professional venture funds. Revue de l'Entrepreneuriat 12, no. 4: 59-78.

Bottazzi, L., Da Rin, M., Hellmann, T. 2008. Who are the active investors? Evidence from venture capital. Journal of Financial Economics 89, no. 3: 488-512.

Bottazzi, L., Da Rin, M., Hellmann, T. 2011. The importance of trust for investment: Evidence from venture capital. Available at: http://www.nber.org/papers/w16923.

Bradford, C. S. 2012. Crowdfunding and the Federal Securities Laws. Columbia Business Law Review 2012, no. 1, 5-150.

Brander, J., Amit, R., Antweiler, W. 2002. Venture capital syndication: Improved venture selection versus the value-added hypothesis. Journal of Economics and Management Strategy 11, no. 3: 423-452.

Brown, R., Mawson, S., Rowe, A., Mason, C. M. 2015. Harnessing the Crowd: The DemandSide Dynamics of Equity Crowdfunding in Nascent Entrepreneurial Ventures. Working papers in responsible banking and finance, 15-009. University of St Andrews.

Bruton, G., Chahine, S., Filatotchev, I. 2009. Founders, Private Equity Investors, and Underpricing in Entrepreneurial IPOs. Entrepreneurship Theory and Practice 33, no. 4: 909-928.

Bruton, G. D., Fried, V. H., Manigart, S. 2005. Institutional Influences on the Worldwide Expansion of Venture Capital. Entrepreneurship Theory and Practice 29, no. 6: 73760.

Bruton, G., Khavul, S., Siegel, D., Wright, M. 2015. New Financial Alternatives in Seeding Entrepreneurship: Microfinance, Crowdfunding, and Peer-to-Peer Innovations. Entrepreneurship Theory and Practice 39, no. 1: 9-26.

Bygrave, W. D. 1987. Syndicated investments by venture capital firms: a networking perspective. Journal of Business Venturing 2, no. 2: 139-154.

Bygrave, W. D. 1988. The Structure of the Investment Networks of Venture Capital Firms. Journal of Business Venturing 3, no. 2: 137-157.

Capizzi, V. 2011. What Drives the Returns of Business Angels' Investments? An Empirical Analysis of the Italian Informal Venture Capital Market. Available at: http://ssrn.com/abstract=1930181. 
Capizzi, V. 2015. The returns of business angel investments and their major determinants. Venture Capital: An International Journal of Entrepreneurial Finance 17, no. 4: 271298.

Capizzi, V., Valetta, M., Zocchi, P. 2016. The determinants of business angels' investment choices: the role of experience, networking monitoring, and co-investments. Available at: http://www.em-

lyon.com/minisiteen/content/download/169401/6656778/file/Capizzi,\%20Valletta,\%2 0Zocchi\%20-

$\%$ 20The $\%$ 20determinants $\% 20$ of $\% 20$ business $\% 20$ angels $\%$ E2\%80\%99\%20investment $\% 20$ choices $\% 20$ the $\% 20$ role $\% 20$ of $\% 20$ experience, $\% 20$ networking $\% 20$ monitoring, $\% 2$ 0and\%20co-investments.pdf.

Campbell, T. L., Frye, M. B. 2008. Venture capitalist monitoring: Evidence from governance structures. The Quarterly Review of Economics and Finance 49, no. 2: 265-282.

Carey, M., Prowse, S., Rea, J., Udell, G. F. 1993. The economics of private placements: A new look, Financial Markets, Institutions and Instruments 2.

Carpentier, C., Suret, J. 2015. Angel group members' decision process and rejection criteria: A longitudinal analysis. Journal of Business Venturing 30, no. 6: 808-821.

Casamatta, C., Haritchabalet, C. 2007. Experience, screening and syndication in venture capital investments. Journal of Financial Intermediation 16, no. 3: 368-398.

Chahine, S., Filatotchev, I., Wright, M. 2007. Venture Capitalists, Business Angels, and Performance of Entrepreneurial IPOs in the UK and France. Journal of Business Finance and Accounting 34, no. 3-4: 505-528.

Chemmanur, T. J., Tian, X. 2011. Peer Monitoring, Syndication, and the Dynamics of Venture Capitalist Interactions. Available at: https://ssrn.com/abstract=1343116.

Cherif, M., Gazdar, K. 2011. What drives venture Capital Investments in Europe? New results from a panel data analysis. Journal of Applied Business Economics 12, no. 3: 122-139.

Cholakova, M., Clarysse, B. 2015. Does the Possibility to Make Equity Investments in Crowdfunding Projects Crowd Out Reward-Based Investments? Entrepreneurship: Theory and Practice 39, No. 1, 145-172.

Cochrane, J. H. 2005. The risk and return of venture capital. Journal of Financial Economics 75 , no. $1: 3-52$.

Collewaert, V. 2008. When is Conflict (Not) Good for Business: The Case of Business Angels and Entrepreneurial Teams. Frontiers of Entrepreneurship Research 28, no. 2: article 2 .

Colombo, M. G., Franzoni, C., Rossi-Lamastra, C. 2015. Internal Social Capital and the Attraction of Early Contributions in Crowdfunding. Entrepreneurship Theory and Practice 39, no. 1: 75-100.

Cooper, A. C. 1985. The Role of Incubator Organizations in the Founding of GrowthOriented Firms. Journal of Business Venturing 1, no. 1: 75-86.

Cooper, I. A., Carleton, W. T. 1979. Dynamics of Borrower-Lender Interaction: Partitioning Final Payoff in Venture Capital Finance. Journal of Finance 34, no. 2: 517-529.

Croce, A., Guerini, M., Ughetto, E. 2016a. Angel Financing and the Performance of HighTech Start-Ups. Journal of Small Business Management, forthcoming.

Croce, A., Tenca, F., Ughetto, E. 2016b. How business angel groups work: Rejection criteria in investment evaluation. International Small Business Journal. In press.

Cumming, D. 2005. Capital structure in venture finance. Journal of Corporate Finance 11, no. 3: $550-585$.

Cumming, D. 2008. Contracts and Exits in Venture Capital Finance. The Review of Financial Studies 21, no. 5: 1947-1982. 
Cumming, D., Johan, S. 2007. Advice and Monitoring in Venture Finance. Financial Markets and Portfolio Management 21, no. 1: 3-43.

Cumming, D., Johan, S. 2008. Information Asymmetries, Agency Costs and Venture Capital Exit Outcomes. Venture Capital: An International Journal of Entrepreneurial Finance 10, no. 3: 197-231.

Cumming, D., MacIntosh, J. G. 2001. Venture capital investment duration in Canada and the United States. Journal of Multinational Financial Management 11, no. 4-5: 445-463.

Cumming, D., MacIntosh, J. G. 2003. A cross-country comparison of full and partial venture capital exits. Journal of Banking and Finance 27, no. 3: 511-548.

Cumming, D., Zhang, Y. 2016. Alternative investments in emerging markets: A review and new trends. Emerging Markets Review 29: 1-29.

Cumming, D., Fleming, G., Schwienbacher, A. 2006. Legality and venture capital exits. Journal of Corporate Finance 12, no. 2: 214-245.

Cumming, D., Schmidt, D., Walz, U. 2010. Legality and venture capital governance around the world. Journal Business Venturing 25, no. 1: 54-72.

Da Rin, M., Hellmann, T., Puri, M. 2013. A Survey of Venture Capital Research. Handbook of Economics and Finance 2, no. A: 573-648.

Daily, C. M., Certo, T. S., Dalton, D. R., Roengpitya, R. 2003. IPO Underpricing: A MetaAnalysis and Research Synthesis. Entrepreneurship Theory and Practice 27, no. 3: 271-295.

De Clercq, D., Fried, V. H., Lehtonen, O., Sapienza, H. J. 2006. An entrepreneur's guide to the venture capital galaxy. Academy of Management Perspectives 20, no. 3: 90-112.

Devigne, D., Manigart, S. 2013. Investment Strategies of Cross-Border Venture Capital Investors. Venture Capital: An International Journal of Entrepreneurial Finance 33, no. 2: 1-15.

Devigne, D., Manigart, S., Wright, M. 2016. Escalation of commitment in venture capital decision making: Differentiating between domestic and international investors. Journal of Business Venturing 31, no. 3: 253-271.

Drover, W., Wood, M. S., Zacharakis, A. 2017. Attributes of Angel and Crowdfunded Investments as Determinants of VC Screening Decisions. Entrepreneurship Theory and Practice 41, no. 3: 323-347.

Dubocage, E., Galindo, G. 2014. Understanding founder-CEO's replacement in venturebacked companies: A theoretical and empirical analysis. European Management Journal 32, no. 3: 461-474.

Dushnitsky, G., Guerini, M., Piva, E., Rossi-Lamastra, C. 2016. Crowdfunding in Europe: Determinants of Platform Creation across Countries. California Management Review 58, no. 2: 44-71.

Dutta, S., Folta, T. B. 2016. A comparison of the effect of angels and venture capitalists on innovation and value creation. Journal of Business Venturing 31, no. 1: 39-54.

Elitzur, R., Gavious, A. 2003. Contracting, signaling, and moral hazard: a model of entrepreneurs, 'angels,' and venture capitalists. Journal of Business Venturing 18, no. 6: 709-725.

Enterprise Research Centre. 2014. Survey of business angels: Interim report. London: ERC/UKBAA.

European Crowdfunding Network. 2014. Review of Crowdfunding Regulation: Interpretations of Existing Regulation Concerning Crowdfunding in Europe, North America, and Israel, 2014. European Crowdfunding Network AISBL.

Everett, C. R. 2014. Origins and Development of Credit-Based Crowdfunding. Available at: https://ssrn.com/abstract=2442897. 
Felipe, I. J. dos S., Mendes-da-Silva, W., Gattaz, C. C. 2017. Crowdfunding Research Agenda. 2017 IEEE 11th International Conference on Semantic Computing. Available at: https://ssrn.com/abstract $=2945355$.

Félix, E. G. S., Gulamhussen, M. A., Pires, C. P. 2007. The determinants of venture capital in Europe - evidence across countries. Journal of Financial Services Research 44, no. 3: 259-279.

Fenn, G. W., Liang, N., Prowse, S. 1997. The Private Equity Market: An Overview. Financial Markets, Institutions and Instruments 6, no. 4: 1-106.

Fitza, M., Matusik, S. F., Mosakowski, E. 2009. Do VCs Matter? The Importance of Owners on Performance Variance in Start-up Firms. Strategic Management Journal 30, no. 4: 387-404.

Fraser, S., Bhaumik, S. K., Wright, M. 2015. What do we know about entrepreneurial finance and its relationship with growth? International Small Business Journal 33, no. 1: 7088.

Freear, J., Sohl, J. E., Wetzel, W.E. 1994. Angels and non-Angels: Are there differences? Journal of Business Venturing 9, no. 2: 109-123.

Freear, J., Sohl, J. E., Wetzel, W.E. 1995. Angels: Personal investors in the venture capital market. Entrepreneurship and Regional Development 7, no. 1: 85-94.

Gill, A., Waltz, U. 2013. Why do so many VC-backed IPOs end up in takeovers? Available at: https://www.wu.ac.at/fileadmin/wu/d/i/finance/BBS.../Andrej_Gill_20112013.pdf.

Gilson, R. J., Schizer, D. M. 2003. Venture capital structure: a tax explanation for convertible preferred stock. Harvard Law Review 116, 875-916.

Goldfarb, B. D., Hoberg, G., Kirsch, D., Triantis, A. 2014. Are Angels Different? An Analysis of Early Venture Financing. Robert H. Smith School Research Paper No. RHS 06-072.

Gompers, P. A. 1994. The Rise and Fall of Venture Capital. Business and Economic History 23, no. 2: 1-24.

Gompers, P. A. 1995. Optimal Investment, Monitoring, and the Staging of Venture Capital. Journal of Finance 50, no. 5: 1461-1489.

Gompers, P. A. 2005. Optimal Investment, Monitoring, and the Staging of Venture Capital. The Journal of Finance 50, no. 5: 1461-1489.

Gompers, P. A., Lerner, J. 1998. What drives venture capital fundraising? Brookings Papers on Economic Activity, Microeconomics, 149-204.

Gompers, P. A., Lerner, J. 2001. The Venture Capital Revolution. The Journal of Economic Perspectives 15, no. 2: 145-168.

Gompers, P. A., Lerner, J., Scharfstein, D. S. 2005. Entrepreneurial Spawning: Public Corporations and the Genesis of New Ventures, 1986 to 1999. Journal of Finance 60, no. 2: 577-614.

Gompers, P., Kovner, A., Lerner, J., Scharfstein, D. S. 2006. Skill vs. Luck in Entrepreneurship and Venture Capital: Evidence from Serial Entrepreneurs. Available at: https://ssrn.com/abstract=933932.

Gompers, P., Kovner, A., Lerner, J., Scharfstein, D. S. 2008. Venture capital investment cycles: The impact of public markets. Journal of Financial Economics 87, no. 1: 1-23.

Gompers, P., Kovner, A., Lerner, J., Scharfstein, D. S. 2010. Performance Persistence in Entrepreneurship and Venture Capital. Journal of Financial Economics 96, no. 1: 731764.

Gorman, M., Sahlman, W. A. 1989. What do venture capitalists do? Journal of Business Venturing 4, no. 4: 213-248.

Gray, D. A., Nattrass, B.F. 1993. Raising money: The Canadian guide to successful business financing. Whitby, ON: McGraw-Hill Ryerson. 
Gregson, G., Mann, S., Harrison, R. 2013. Business Angel Syndication and the Evolution of Risk Capital in a Small Market Economy: Evidence from Scotland. Managerial and Decision Economics 34, no. 2: 95-107.

Griffin, Z. J. 2013. Crowdfunding: Fleecing the American Masses. Journal of Law, Technology and the Internet 4, no. 2: 375-410.

Groh, A. P., Bertoni, F. 2014. Cross-Border Investments and Venture Capital Exits in Europe. Global Perspectives on Entrepreneurship: Public and Corporate Governance 22, no. 2: 84-99.

Groh, A. P., von Liechtenstein, H. 2009. How attractive is central Eastern Europe for risk capital investors? Journal of International Money and Finance 28, no. 4: 625-647.

Groh, A. P., Wallmeroth, J. 2016. Determinants of venture capital investments in emerging markets. Emerging Markets Review 29: 104-132.

Gupta, A. K., Sapienza, H. 1992. Determinants of venture capital firms' preferences regarding the industry diversity and geographic scope of their investments. Journal of Business Venturing 7, no. 5: 347-362.

Hainz, C., Hornuf, L. 2016. Crowdinvesting. CESifo DICE Report 14, no. 1: 67-69.

Harrison, R., Mason, C. 2000. Venture capital market complementarities: the links between business angels and venture capital funds in the United Kingdom. Venture Capital 2, no. 3: 223-242.

Harrison, R., Mason, C., Robson, P. 2010. Determinants of long-distance investing by business angels in the UK. Journal Entrepreneurship and Regional Development an International Journal 22, no. 2: 113-137.

Hart, O., Helmström, B. 2016. Contractual Theory. The Royal Swedish Academy of Sciences. Available at: https://www.nobelprize.org/nobel_prizes/economicsciences/laureates/2016/advanced-economicsciences2016.pdf.

Hellmann, T. 1994. Financial Structure and Control in Venture Capital. Stanford University Working Paper.

Hellmann, T. 1998. The Allocation of Control Rights in Venture Capital Contracts. The RAND Journal of Economics 29, no. 1: 57-76.

Hellmann, T. 2002. A theory of strategic venture investing. Journal of Economic Finance 64, no. 2: 285-314.

Hellmann, T. 2006. IPOs, acquisitions, and the use of convertible securities in venture capital. Journal of Financial Economics 81, no. 3: 649-679.

Hellmann, T., Thiele, V. 2015. Friends or foes? The interrelationship between angel and venture capital markets. Journal of Financial Economics 115, no. 3: 639-653.

Hellmann, T., Puri, M. 2002. Venture Capital and the Professionalization of Start-Up Firms: Empirical Evidence. Journal of Finance 57, no. 1: 169-197.

Hervé, F., Manthe, E., Sanajust, A., Schwienbacher, A. 2016. Investor Motivations in Investment-based Crowdfunding. Available at SSRN: http://ssrn.com/abstract=2746398.

Hindle, K., Lee, L. 2002. An exploratory investigation of informal venture capitalists in Singapore. Venture Capital: An International Journal of Entrepreneurial Finance 4, no. 2: $169-82$.

Hoban, J. P. 1978. Characteristics of Venture Capital Investments. Financial Review 13, no. 1: 104-106.

Hochberg, Y. V., Lindsey, L. A., Westerfield, M. M. 2015. Partner Selection in CoInvestment Networks: Evidence from Venture Capital. Available at: https://ssrn.com/abstract $=1855764$.

Hochberg, Y. V., Ljungqvist, A., Lu, Y. 2007. Whom you know matters: Venture Capital Networks and Investment Performance. The Journal of Finance 62, no. 1: 251-301. 
Hornuf, L., Schmitt, M. 2016a. Does a local bias exist in equity crowdfunding? The impact of investor types and portal design. Available at: http://ssrn.com/abstract=2801170.

Hornuf, L., Schmitt, M. 2016b. Success and failure in equity crowdfunding. CESifo DICE Report 2/2016. Available at: https://www.unitrier.de/fileadmin/fb4/prof/VWL/OAR/Hornuf_Schmitt_Success_and_Failure_in_Equity_Crowdfunding.pdf.

Hornuf, L., Schwienbacher, A. 2014. Crowdinvesting - Angel Investing for the Masses? Handbook of Research on Venture Capital, 3.

Hornuf, L., Schwienbacher, A. 2015a. The Emergence of Crowdinvesting in Europe: With an In-Depth Analysis of the German Market. Available at: http://ssrn.com/abstract=2481994.

Hornuf, L., Schwienbacher, A. 2015b. Should Securities Regulation Promote Crowdinvesting? Available at: http://ssrn.com/abstract=2412124.

Hornuf, L., Schwienbacher, A. 2016. Portal Design and Funding Dynamics in Equity Crowdfunding. Available at: http://www.emlyon.com/minisiteen/content/download/169415/6656834/file/Hornuf,\%20\%20Schwie nbacher $\% 20$ -

\%20Portal\%20Design\%20and\%20Crowd\%20Dynamics\%20in\%20equity \%20crowdfu nding.pdf.

Ibrahim, D. M. 2008. The (not so) puzzling behavior of angel investors. Vanderbilt Law Review 61, 1405-1452.

Jeng, L. A., Wells, P. C. 2000. The determinants of venture capital funding: evidence across countries. Journal of Corporate Finance 6, no. 3: 241-289.

Jensen, M., Meckling, W. 1976. Theory of the Firm: Managerial behavior, agency costs, and ownership structure. Journal of Financial Economics 3, 78-133.

Kandel, E., Leshchinskii, D., Yuklea, H. 2011. VC Funds: Aging Brings Myopia. Journal of Financial and Quantitative Analysis 46, no. 2: 431-457.

Kaplan, S. N., Lerner, J. 2010. It Ain't Broke: The Past, Present, and Future of Venture Capital. Journal of Applied Corporate Finance 22, no. 2: 36-47.

Kaplan, S. N., Schoar, A. 2005. Private Equity Performance: Returns, Persistence, and Capital Flows. Journal of Finance 60, no. 4: 1791-1823.

Kaplan, S. N., Strömberg, P. 2002. Financial Contracting Theory Meets the Real World: An Empirical Analysis of Venture Capital Contracts. Review of Economic Studies 70, no. 2: 281-315.

Kaplan, S. N., Strömberg, P. 2004. Characteristics, Contracts, and Actions: Evidence from Venture Capitalist Analyses. The Journal of Finance 59, no. 5: 2177-2210.

Kaplan, S. N., Martel, F., Strömberg, P. 2007. How do legal differences and experience affect financial contracts? Journal Financial Intermediation 16, no. 3: 273-311.

Kaplan, S. N., Klebanov, M. M., Sorensen, M. 2012. Which CEO Characteristics and Abilities Matter? Journal of Finance 67, no. 3: 973-1007.

Kerr, W. R., Lerner, J., Schoar, A. 2014. The Consequences of Entrepreneurial Finance: A Regression Discontinuity Analysis. Harvard Business School Working Paper.

Khavul, S., Deeds, D. 2016. The Evolution of Initial Co-investment Syndications in an Emerging Venture Capital Market. Journal of International Management 22, no. 3 : 280-293.

Klöhn, L., Hornuf, L. 2012. Crowdinvesting in Deutschland. Journal of Banking Law and Banking 4: 237-320.

Klöhn, L., Hornuf, L., Schilling, T. 2015. The Regulation of Crowdfunding in the German Small Investor Protection Act: Content, Consequences, Critique, Suggestions. Diritto Della Banca e del Mercato Finanziario, forthcoming. 
Klöhn, L., Hornuf, L., Schilling, T. 2016. Financial Contracting in Crowdinvesting: Lessons from the German Market. Available at: https://ssrn.com/abstract=2839041.

Kuppuswamy, V., Bayus, B. L. 2015. Crowdfunding Creative Ideas: The Dynamics of Project Backers in Kickstarter. Available at: https://ssrn.com/abstract=2234765.

La Porta, R., Lopez-de-Silanes, F., Shleifer, A. 2006. What Works in Securities Laws? The Journal of Finance 61, no. 1: 1-32.

La Porta, R., Lopez-de-Silanes, F., Shleifer, A., Vishny, R. W. 1998. Law and Finance. Journal of Political Economy 106, no. 6: 1113-1155.

La Porta, R., Lopez-de-Silanes, F., Shleifer, A., Vishny, R. W. 2000. Investor Protection and Corporate Governance. Journal of Financial Economics 58, no. 1-2: 3-27.

Landström, H. 1993. Informal risk capital in Sweden and some international comparisons. Journal of Business Venturing 8, no. 6: 525-540.

Leavitt, J. M. 2005. Burned Angels: The Coming Wave of Minority Shareholder Oppression Claims in Venture Capital Start-up Companies. North Carolina Journal of Law and Technology 6, no. 2: 223-286.

Leleux, B., Surlemont, B. 2003. Public versus private venture capital: seeding or crowding out? A pan European analysis. Journal of Business Venturing 18, no. 1: 81-104.

Lerner, J. 1994a. The Syndication of Venture Capital Investments. Financial Management 23, no. 3: 16-27.

Lerner, J. 1994b. Venture capitalists and the decision to go public. Journal of Financial Economics 35, no. 3: 293-316.

Lerner, J. 1995. Venture capitalists and the oversight of private firms. Journal of Finance 50, 301-318.

Lerner, J. 1998. “Angel” financing and public policy: An overview. Journal of Banking and Finance 22, no. 6-8: 773-783.

Lerner, J., Schoar, A. 2005. Does Legal Enforcement Affect Financial Transactions? The Contractual Channel in Private Equity. Quarterly Journal of Economics 120, no. 1: 223-246.

Ley, A., Weaven, S. 2011. Exploring agency dynamics of crowd funding in start-up capital financing. Academy of Entrepreneurship Journal 17, no. 1: 85-110.

Lin, T., Smith, R. 1998. Insider reputation and selling decisions: the unwinding of venture capital investments during equity IPOs. Journal of Corporate Finance 4, no. 3: 241263.

Lockett, A., Wright, M. 2001. The syndication of venture capital investments. Omega 29, no. 5: 375-390.

Löher, J. 2016. The interaction of equity crowdfunding platforms and ventures: an analysis of the preselection process. Venture Capital: An International Journal of Entrepreneurial Finance 19, no. 1-2: 51-74.

Lukkarinen, A., Teich, J. E., Wallenius, H., Wallenius, J. 2016. Success drivers of online equity crowdfunding campaigns. Decision Support Systems 87: 26-38.

Lumme, A., Mason, C., Suomi, M. 1998. Informal venture capital: Investors, investments and policy issues in Finland. USA: Springer.

MacMillan, I. C., Siegel, R., Narashima, P. B. S. 1985. The Criteria used by Venture Capitalists to Evaluate New Venture Proposals. Journal of Business Venturing 1, no. 1: 119-128.

MacMillan, I. C., Zemann, L., Subbanarasimha, P. N. 1987. Criteria distinguishing successful from unsuccessful ventures in the venture screening process. Journal of Business Venturing 2, no. 2: 123-137. 
Manigart, S., de Waele, K., Wright, M., Robbie, K., Desbrieres, P., Sapianza, H. J., Beekman, A. 2002. Determinants of required return in venture capital investments: a five-country study. Journal of Business Venturing 17, no. 4: 291-312.

Manigart, S., Lockett, A., Meuleman, M., Wright, M., Landström, H., Bruining, H., Desbrières, P., Hommel, U. 2006. Venture Capitalists' Decision to Syndicate. Entrepreneurship: Theory and Practice 30, no. 2: 131-153.

Martin, J. D., Petty, J. W. 1983. An Analysis of the Performance of Publicly Traded Venture Capital Companies. The Journal of Financial and Quantitative Analysis 18, no. 3: 401410.

Mason, C. M. 2006. Informal sources of venture finance. In The lifecycle of entrepreneurial ventures. In S. Parker, The Life Cycle of Entrepreneurial Ventures: Volume 3. International Handbook on Entrepreneurship. Berlin: Springer, 259-299.

Mason C. M., Botelho, T. 2014. The 2014 Survey of Business Angel Investing in the UK: A Changing Market Place. Glasgow: Adam Smith Business School, University of Glasgow.

Mason C. M., Botelho, T., Harrison, R. 2016. The transformation of the business angel market: empirical evidence and research implications. Venture Capital: An International Journal of Entrepreneurial Finance 18, no. 4: 312-344.

Mason, C. M., Harrison, R.T. 1996. Informal venture capital: A study of the investment process, the post-investment experience and investment performance. Entrepreneurship and Regional Development 8, no. 2: 105-26.

Mason, C. M., Harrison, R. T. 1997. Business Angel Networks and the Development of the Informal Venture Capital Market in the U.K.: Is There Still a Role for the Public Sector. Small Business Economics 9, no. 2: 111-123.

Mason, C. M., Harrison, R. T. 2002. Is it worth it? The rates of return from informal venture capital investments. Journal of Business Venturing 17, no. 3: 211-236.

Mason, C., Harrison, R.T., Chaloner, J. 1991. Informal risk capital in the UK: A study of investor characteristics, investment preferences and investment decision-making. Venture Finance Research Project. Working Paper No. 2, University of Southampton.

MIT Entrepreneurship Center. 2000. Venture Support Systems Project: Angel Investors. Available at: https://www.angelcapitalassociation.org/data/Documents/Resources/AngelGroupResa $\mathrm{rch} / 1 \mathrm{~d} \% 20-\% 20$ Resources $\% 20$ \%20Research/35\%20Research_VentureSupportProject.pdf.

Mollick, E. 2014. The dynamics of crowdfunding: An exploratory study. Journal of Business Venturing 29, no. 1: 1-16.

Moore, C. B., Payne, G. T., Bell, R. G., Davis, J. L. 2015. Institutional Distance and CrossBorder Venture Capital Investment Flows. Journal of Small Business Management 53, no. 2: 482-500.

Moritz, A., Block, J., Lutz, E. 2015. Investor Communication in Crowdfunding: A Qualitative-Empirical Study. Qualitative Research in Financial Markets 7, No. 3, 309342.

Morrissette, S. 2007. A Profile of Angel Investors. The Journal of Private Equity 10, no. 3: 52-66.

Nahata, R. 2008. Venture capital reputation and investment performance. Journal of Financial Economics 90, no. 2: 127-151.

Nahata, R., Hazarika, S., Tandon, K. 2015. Success in global venture capital investing: do institutional and cultural differences matter? Journal of Financial Quantitative Analysis 49, no. 4: 1039-1070. 
Norton, E., Tenenbaum, B. H. 1992. Specialization versus diversification as a venture capital investment strategy. Journal of Business Venturing 8, no. 5: 431-442.

Ooghe, H., Manigart, S., Fassin, Y. 1991. Growth patterns of the European venture capital industry. Journal of Business Venturing 6, no. 6: 381-404.

Parhankangas, A., Hellström, T. 2007. How experience and perceptions shape risky behaviour: Evidence from the venture capital industry. Venture Capital: An International Journal of Entrepreneurial Finance 9, no. 3: 183-205.

Paul, S., Whittam, G., Wyper, J. 2007. Towards a Model of the Business Angel Investment Process. Venture Capital: An International Journal of Entrepreneurial Finance 9, no. 2: 107-125.

Politis, D. 2008. Business angels and value added: what do we know and where do we go? Venture Capital: An International Journal of Entrepreneurial Finance 10, no 2: 127 147.

Politis, D., Landström, H. 2002. Informal investors as entrepreneurs: The development of an entrepreneurial career. Venture Capital: An International Journal of Entrepreneurial Finance 4, no. 2: 78-101.

Prowse, S. 1998. Angel investors and the market for angel investments. Journal of Banking and Finance 22, no. 6-8: 785-792.

Reiner, M. L. 1989. The transformation of venture capital: A history of venture capital organizations in the United States. University of California at Berkeley.

Riding, A. L., Haines, G. H. Jr., Madill, J. J. 2003. Informal investment in Canada: financing small business growth. Journal of Small Business and Entrepreneurship 16, no. 3-4: 13-40.

Romain, A., van Pottelsberghe de la Potterie, B. 2004. The determinants of venture capital: a panel data analysis of 16 OECD countries. Université Libre de Bruxelles Working Paper, WP-CEB 04/015.

Rosenstein, J., Bruno, A. V., Bygrave, W. D., Taylor, N. T. 1993. The CEO, Venture Capitalists, and the Board. Journal of Business Venturing 8, no. 2: 99-113.

Rotch, W. 1968. The Pattern of Success in Venture Capital Financing. Financial Analysts Journal 24, no. 5: 141-147.

Ruhnka, J. C., Young, J. E. 1991. Some hypotheses about risk in venture capital investing. Journal of Business Venturing 6, no. 2: 115-133.

Sahlman, W. A. 1988. Aspects of Financial Contracting in Venture Capital. Journal of Applied Corporate Finance 1, no. 2: 23-36.

Sahlman, W. A. 1990. The Structure and Governance of Venture Capital Organizations. Journal of Financial Economics 27, no. 2: 473-521.

Sapienza, H. J., Manigart, S., Vermeir, W. 1996. Venture Capitalist Governance and Value Added in four Countries. Journal of Business Venturing 11, no. 6: 439-469.

Schwienbacher, A. 2009. Financing commitments and investors incentives in entrepreneurial firms. Unpublished working paper.

Schwienbacher, A., Larralde, B. 2010. Crowdfunding of Small Entrepreneurial Ventures. Handbook of Entrepreneurial Finance, Oxford University Press, forthcoming.

Scott, W. R. 1995. Institutions and organizations: Ideas, Interests, and Identities. $4^{\text {th }}$ edition, Sage Publications.

Signori, A., Vismara, S. 2016. Returns on Investments in Equity Crowdfunding. Available at: https://ssrn.com/abstract $=2765488$.

Sorenson, O., Stuart, T. E. 2001. Syndication Networks and the Spatial Distribution of Venture Capital Investments. American Journal of Sociology 106, no. 6: 1546-1588. 
Stevenson, H. H., Muzyka, D. F., Timmons, J. A. 1987. Venture capital in transition: A Monte-Carlo simulation of changes in investment patterns. Journal of Business Venturing 2, no. 2: 103-121.

Swartz, J. 1991. The future of the venture capital industry. Journal of Business Venturing 6, no. 2: 89-92.

Tashiro, Y. 1999. Business angels in Japan. Venture Capital: An International Journal of Entrepreneurial Finance 1, no. 3: 259-273.

Tyebjee, T. T., Bruno, A. V. 1984. A model of venture capitalist investment activity. Management Science 30, no. 9: 1051-1066.

Uhlaner, L., Wright, M., Huse, M. 2007. Private Firms and Corporate Governance: An Integrated Economic and Management Perspective. Small Business Economics 29, no. 3: 225-41.

Van Osnabrugge, M. 1998. Do Serial and Non-Serial Investors Behave Differently?: An Empirical and Theoretical Analysis. Entrepreneurship: Theory and Practice 22, no. 4: 23-42.

Van Osnabrugge, M. 2000. A Comparison of Business Angel and Venture Capitalist Investment Procedures: An Agency Theory-Based Analysis. Venture Capital: An International Journal of Entrepreneurial Finance 2, no. 2: 91-109.

Van Osnabrugge, M., Robinson, R. J. 2000. Angel Investing: Matching Start-up Funds with Start-up Companies. A Guide for Entrepreneurs, Individual Investors, and Venture Capitalists. San Francisco: Jossey-Bass.

Vinig, T., de Haan, M. 2003. How do Venture Capitalists Screen Business Plans? Evidence from The Netherlands and the US. Available at: https://ssrn.com/abstract=321860.

Vismara, S. 2016a. Information Cascades Among Investors in Equity Crowdfunding. Entrepreneurship Theory and Practice, forthcoming.

Vismara, S. 2016b. Equity retention and social network theory in equity crowdfunding. Small Business Economics 46, no. 4: 579-590.

Wallmeroth, J. 2016. Investor Behavior in Crowdinvesting. Available at: https://ssrn.com/abstract $=2881394$.

Walske, J. M., Zacharakis, A., Smith-Doerr, L. 2007. Effects of Venture Capital Syndication Networks on Entrepreneurial Success. Babson College Entrepreneurship Research Conference (BCERC) 2007. Available at: https://ssrn.com/abstract=1060081.

Warne, K. F. 1988. Essays on the Venture Capital Market. Yale University.

Werth, J. C., Boeert, P. 2013. Co-Investment Networks of Business Angels and the Performance of their Start-Up Investments. International Journal of Entrepreneurial Venturing 5, no. 3: 240-256.

Westhead, P., Wright, M. 1998. Novice, portfolio, and serial entrepreneurs: are they different? Journal of Business Venturing 13, no. 3: 173-204.

Weston, J. F., Brigham, E. F. 1978. Managerial Finance $6^{\text {th }}$ edition, Dryden Press.

Wetzel, W. E. 1983. Angels and informal risk capital. Sloan Management Review 24, no. 4: 23-34.

Wetzel, W. E. 1987. The informal venture capital market: aspects of scale and market efficiency. Journal of Business Venturing 2, no. 4: 299-313.

Wetzel, W. E. 1994. Venture capital, Portable MBA in entrepreneurship $4^{\text {th }}$ edition, Bygrave, W. D., Zacharakis, A. New York: John Wiley and Sons, 172-194.

Wetzel, W. E., Seymour, C. R. 1981. Informal risk capital in New England. Center for Industrial and Institutional Development. University of New Hampshire, Durham, $\mathrm{NH}$.

Wiltbank, R., Boeker, W. 2007. Returns to angel investors in groups. Available at: http://ssrn.com/paper=1028592. 
Wiltbank, R., Read, S., Dew, N., Sarasvathy, S. D. 2009. Prediction and control under uncertainty: Outcomes in angel investing. Journal of Business Venturing 24, no. 2: 116-133.

Wirtz, P. 2011. Beyond Agency Theory: Value Creation and the Role of Cognition in the Relationship Between Entrepreneurs and Venture Capitalists. In Advances in Entrepreneurial Finance, ed. R. Yazdiour, 31-43. New York: Springer.

Wong, A., Bhatia, M., Freeman, Z. 2009. Angel finance: the other venture capital. Special Issue: Entrepreneurial Finance 18, no. 7-8: 221-258.

Wright, M., Hart, M., Fu, K. 2015. A Nation of Angels: Assessing the impact of angel investing across the UK. Enterprise Research Centre.

Wright, M., Lockett, A., Pruthi, S. 2002. Internationalization of Western venture capitalists into emerging markets: Risk assessment and information in India. Small Business Economics 19, no. 1: 13-29.

Wright, M., Robbie, K., Ennew, C. 1997. Venture capitalists and serial entrepreneurs. Journal of Business Venturing 12, no. 3: 227-249.

Wroldsen, J. 2016. Crowdfunding Investment Contracts. Virginia Law and Business Review, forthcoming. 


\section{Appendix}

Figure 1

Economic functions of the financial mechanisms

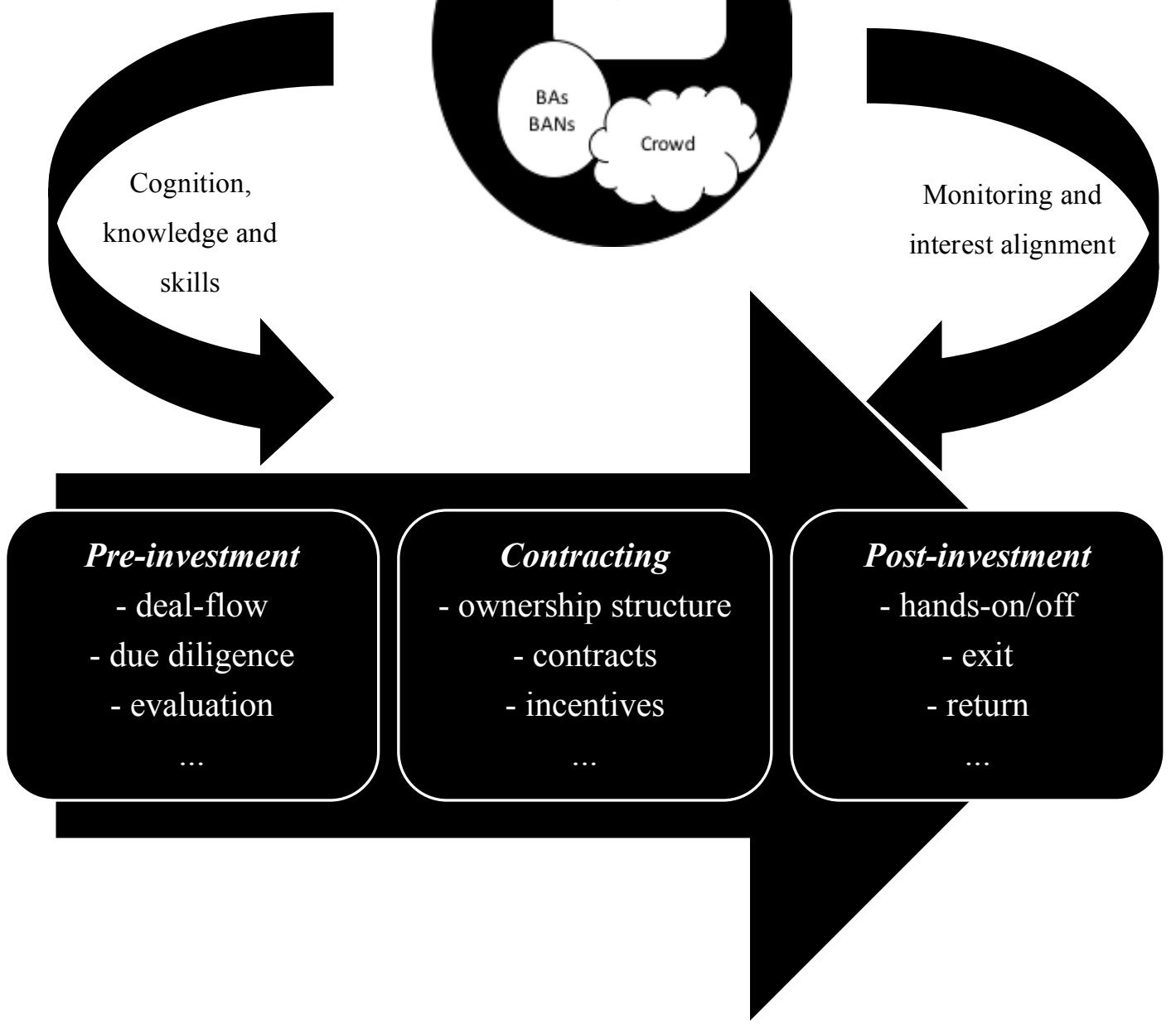


Figure 2

\section{Scopus publication statistics}

In this chart, we show the results of the keyword search performed on Scopus. The results range from 1978 to 2016. Black: "Venture Capital"; Red: "Business Angels"; Green: "Crowdfunding".

Publication Statistics (Scopus)

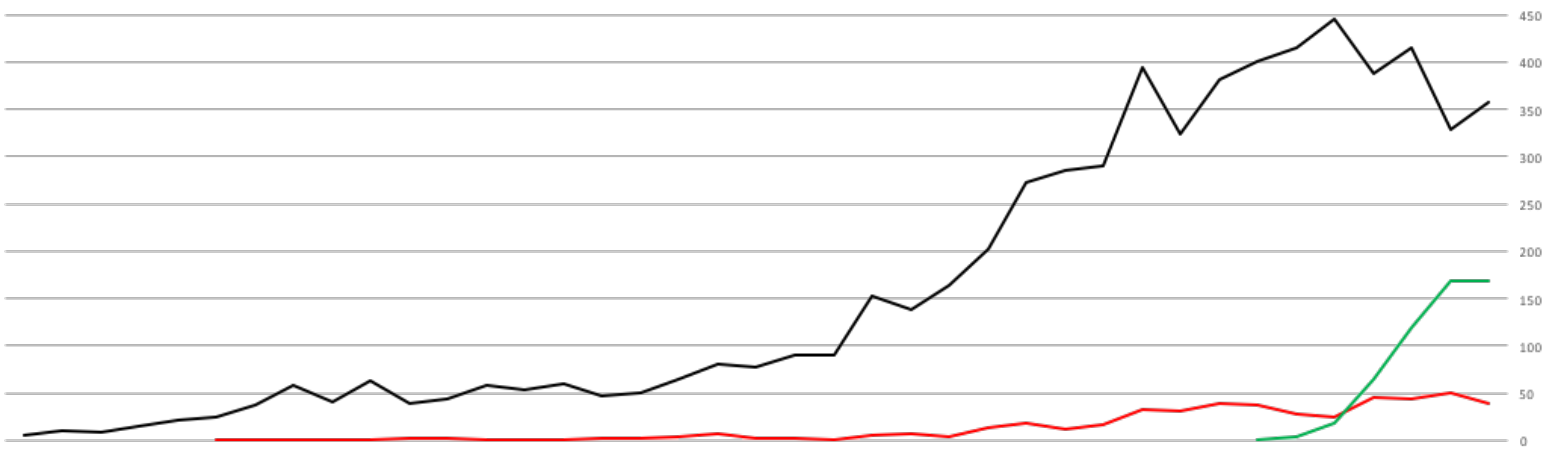

197919791980198119821983198419851986198719981989199019911992199319941995199619971998199920002001200220032004200520062007200820092010201120122013201420152016 


\section{Figure 3}

Publication statistics for Venture Capital publications by decade

In this chart, we show the results of the keyword search performed on Scopus. The results range from 1940 to 2016.

\section{Venture Capital}

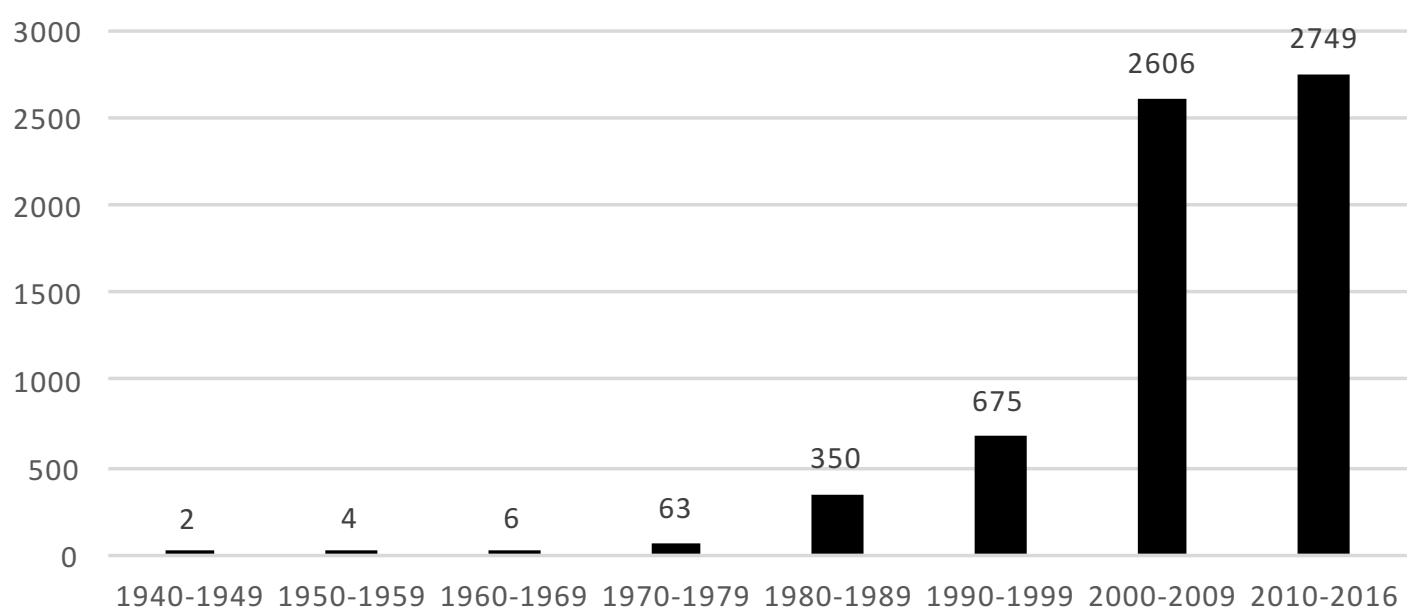


Figure 4

The market for entrepreneurial finance and its evolution over time (as reflected in research)

\begin{tabular}{|ll|}
\hline \multicolumn{1}{c|}{$\mathbf{1 9 8 0}$} & \multicolumn{1}{c}{ Now } \\
\hline VC investments & VC investments \\
VC syndication & VC syndication \\
BA investments & BA investments \\
BA syndication & BA syndication \\
& BAN investments \\
& BA/VC co-investments \\
& BAN/VC co-investments \\
& Equity crowdfunding investments \\
& BA/Equity crowdfunding co-investments \\
& VC/Equity crowdfunding co-investments
\end{tabular}




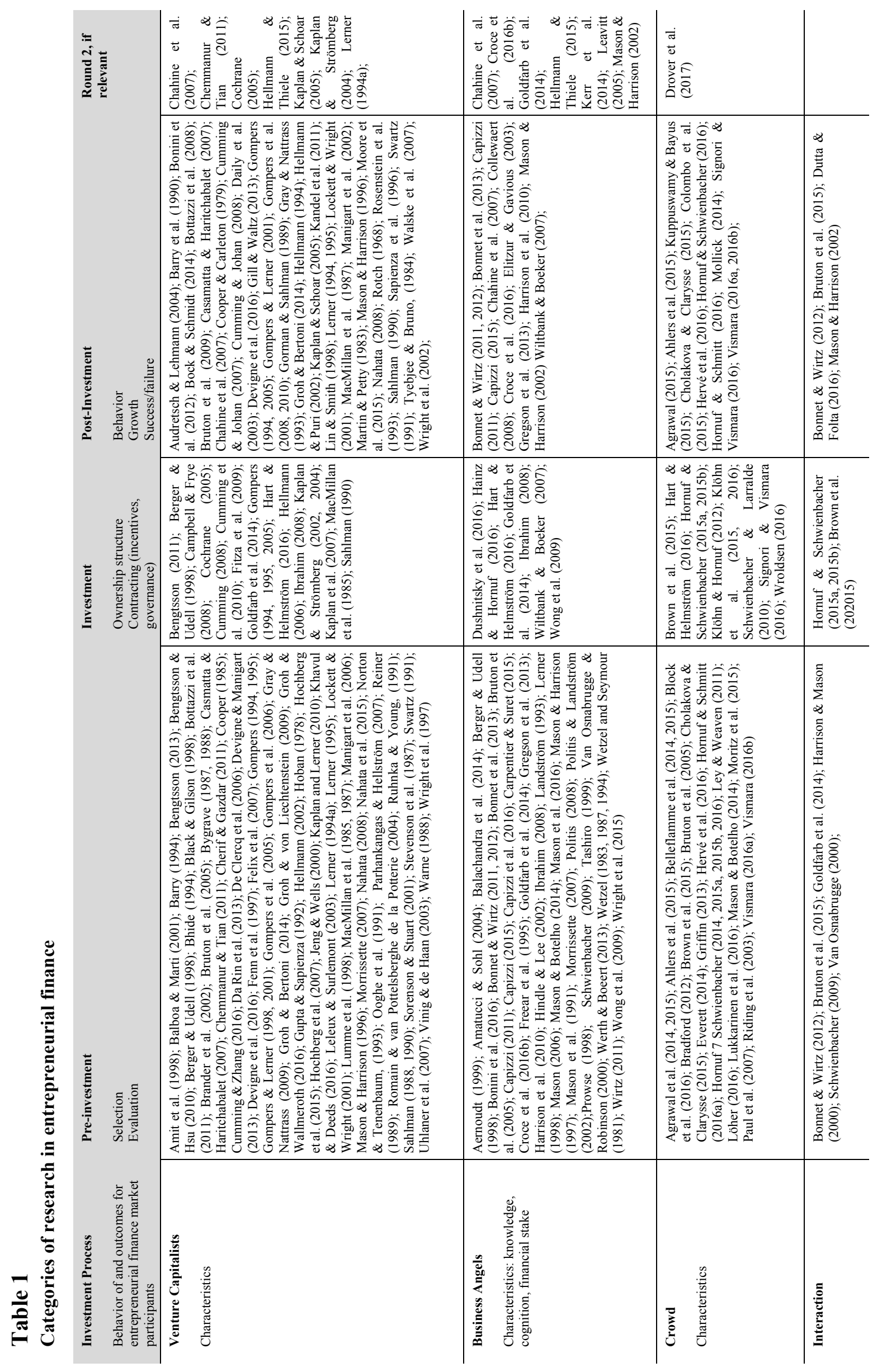




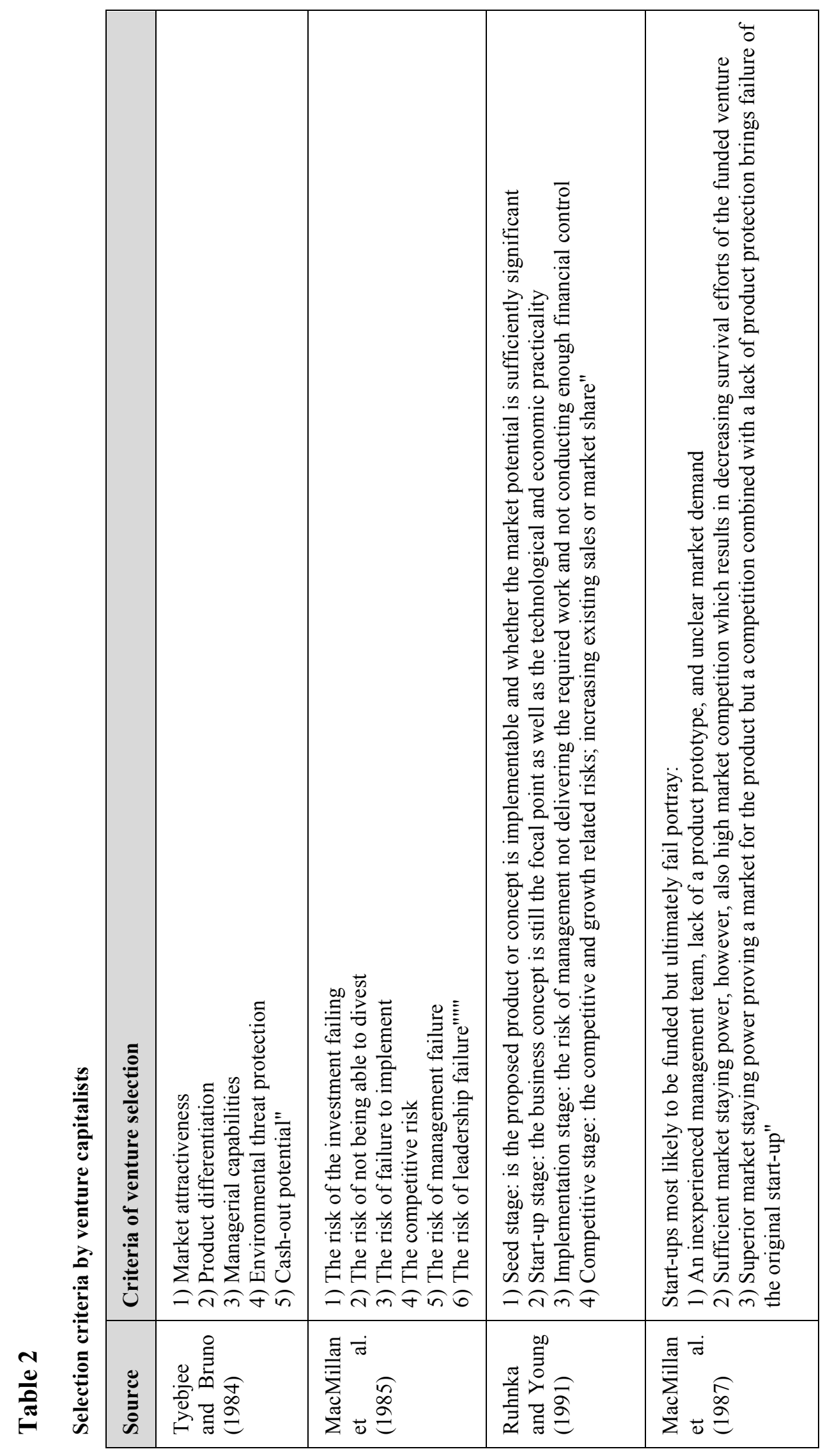


Table 3

Differences between business angels and venture capitalists

Source: Morrissette (2007).

\begin{tabular}{|l|l|l|}
\hline & Business Angels & Venture Capital \\
\hline Funding Source & Angel's own money & Investors \\
\hline Number of deals per year & One every two years & 5-10 per year \\
\hline $\begin{array}{l}\text { Typical investment per } \\
\text { company }\end{array}$ & $\begin{array}{l}\$ 25,000-250,000 ; \text { average } \\
\$ 50,000-75,000\end{array}$ & $\begin{array}{l}\$ 1-10 \text { million; average } \$ 4 \\
\text { million }\end{array}$ \\
\hline Company stage & Small, start-up, early stage & Larger, expansion stage \\
\hline Geographic focus & $\begin{array}{l}\text { Usually near (within one to } \\
\text { two hours) of home }\end{array}$ & $\begin{array}{l}\text { Usually nationwide, } \\
\text { sometimes regional }\end{array}$ \\
\hline Industry focus & $\begin{array}{l}\text { No focus, but prefer } \\
\text { industries they know }\end{array}$ & $\begin{array}{l}\text { Often focus on one or two } \\
\text { industries }\end{array}$ \\
\hline Source of deals & $\begin{array}{l}\text { Other angels, friends, } \\
\text { business contacts }\end{array}$ & $\begin{array}{l}\text { Proposals submitted, other } \\
\text { VCs }\end{array}$ \\
\hline Decision maker & $\begin{array}{l}\text { Individual, experienced } \\
\text { entrepreneur, personal, 50 } \\
\text { years old }\end{array}$ & $\begin{array}{l}\text { Professional, MBAs, } \\
\text { committees, 40-year-olds }\end{array}$ \\
\hline Analysis / Due diligence & $\begin{array}{l}\text { Minimal, informal, } \\
\text { subjective, judgment }\end{array}$ & $\begin{array}{l}\text { Extensive, formal, } \\
\text { analytical, spreadsheets }\end{array}$ \\
\hline Investment structure & Simple, common stock & $\begin{array}{l}\text { Complex, Convertible } \\
\text { Preferred Stock }\end{array}$ \\
\hline Involvement & Hands-on & Strategic, Board Seat \\
\hline Investment time / Horizon & Longer, five or more years & Shorter, three to five years \\
\hline Exit/ Harvest strategy & $\begin{array}{l}\text { Less important, long-term } \\
\text { investment horizon }\end{array}$ & $\begin{array}{l}\text { Important, IPO or Sell } \\
\text { Company }\end{array}$ \\
\hline $\begin{array}{l}\text { Return on investment } \\
\text { expectations } \\
\text { predetermined ROI } \\
\text { expectation }\end{array}$ & Expect 30-50\% ROI \\
\hline
\end{tabular}

